\title{
Ethical and Legal Considerations for Canadian Registries
}

\author{
David B. Hogan ${ }^{1}$, Janet Warner ${ }^{2}$, Scott Patten ${ }^{2}$, Glenys Godlovitch ${ }^{2}$, \\ Essie Mehina ${ }^{2}$, Lynn Dagenais ${ }^{3}$, Guillermo Fiebelkorn ${ }^{2}$, Paula de Robles ${ }^{2}$, \\ Gail MacKean ${ }^{2}$, Lisa Casselman ${ }^{2}$, Nathalie Jette ${ }^{1,4}$, Tamara Pringsheim², \\ Lawrence Korngut ${ }^{1}$, Megan Johnston ${ }^{2}$
}

Can J Neurol Sci. 2013; 40: Suppl. 2 - S5-S23

This section summarizes the ethical and legal considerations that will impact the creation and operation of neurological disease registries in Canada. This document is not meant to provide legal or ethical advice. In order to ensure that applicable laws and organizational policies are adhered to in an appropriate manner, it is recommended that legal advisors and relevant organizational representatives be consulted. For registries to succeed, it is critical to proactively consider legal and ethical issues such as consent and privacy. Additional ethical and legal considerations include: the involvement of Aboriginal people and their communities, languages and communication; setting up of biobanks; data management; data ownership; and conducting transparent registry operations.

The Belmont Report - Ethical Principles and Guidelines for the protection of human subjects of research ${ }^{6}$ and the Government of Canada Tri-Council Policy Statement: Ethical Conduct for Research Involving Humans (TCPS-2) ${ }^{7}$ should be referred to for the ethical principles that need to be considered during the creation of disease registries. In addition, Registries for Evaluating Patient Outcomes: A User's Guide ${ }^{5}$ produced by The Agency for Healthcare Research and Quality provides useful information. However, this document presents perspectives and reviews legislation particularly relevant to the United States which differ in some respects from Canadian law and research policies and practice.

In preparation of this guideline, we examined relevant Canadian and international literature as well as Canadian policy and legislation. We also consulted with Canadian privacy officers and specialists in research ethics. Finally, topic themes and issues were discussed with patients and families in project focus groups.

\section{BACKGROUND}

In Canada, Research Ethics Boards (REBs) are the equivalent of what is more commonly known as Institutional Review Boards (IRBs) in other jurisdictions. The TCPS-2 describes the authority, mandate and accountability of REBs. In some cases, provincial and federal legislation also applies. While investigators should consult with their local REB for information that is specific to their institution and province/ territory, general overview of REBs is provided here.

1) REBs are established by the highest body governing an institution, to review the ethical acceptability of research conducted within their jurisdiction. Provincial legislation often discusses an institution's jurisdiction. REBs may be internal or external to an institution depending on arrangements made with external agencies.

2) The composition of an REB and the number of REBs will depend on the range and scope of research carried out within the jurisdiction.

3) REBs must operate independently and must be free from real or perceived conflicts of interest. They must also be provided sufficient financial and administrative resources by the host institution.

4) REBS have the authority to approve, reject, or request modification of incoming research proposals and also have the authority to terminate ongoing research.

5) REBs must consist of at least five members with a minimum of: two members with expertise in the relevant research discipline; one member who is knowledgeable in the area of ethics; one member who is knowledgeable in relevant law; and at least one community member who has no affiliation with the institution.

6) Institutional senior administrative members may not serve on the REB.

7) REBs shall use a proportionate approach to ethical review determined by the level of foreseeable risk to study participants. Two levels of review are permitted: full board review and delegated review for research with minimal risk.

8) REB review should be continuous throughout the research duration with at a minimum annual status reports. Researchers must also report unanticipated events with impact on participants in a timely fashion.

9) REBs must maintain appropriate documentation

From the ${ }^{1}$ Hotchkiss Brain Institute, University of Calgary, Calgary, Alberta; ${ }^{2}$ University of Calgary, Calgary, Alberta; ${ }^{3}$ McGill University, Montreal, Quebec; ${ }^{4}$ Institute for Public Health, University of Calgary, Calgary, Alberta.

Final REvisions SubmitTEd JANUARY 28, 2013

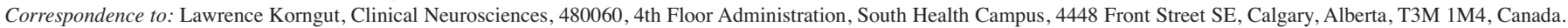
Email: Lawrence.korngut@albertahealthservices.ca. 
including records of all submissions to the REB as well as attendance and minutes for REB meetings.

10) REBs must have a mechanism for reconsideration or appeal of REB decisions.

In general, most registry projects will require REB review as they involve living human participants or human biological materials (tissues, organs, blood, plasma, serum, skin, hair, nails, DNA, RNA, proteins, urine, saliva or other body fluid) and the extension of knowledge through disciplined inquiry or systematic investigation which is the TCPS-2 definition of "research". Registry projects in a single jurisdiction will require only their local REB approval; however, projects being conducted in multiple jurisdictions may encounter additional challenges. In general operating a registry in multiple jurisdictions involves the need to apply to multiple REBs (one or more per jurisdiction) depending on institutional arrangements or agency agreements governing the operation of REBs for each institution and jurisdiction that will be involved in the registry. In some jurisdictions, efforts to reciprocate individual institutional REB review across a broader jurisdiction have been undertaken both formally and informally. TCPS-2 does contain an alternative review model for multi-jurisdictional projects that consisting of review by a single specialized or multijurisdictional ethics board. However, the discretion to form such a multi-jurisdictional ethics board lies with individual institutions and therefore is unlikely to be created solely for project specific purposes. An example of multi-jurisdictional REBs widely seen in Canada is in the area of cancer specific REBs. The province of Ontario, for example, has an "Ontario Cancer Research Ethics Board (OCREB)" which was introduced to help expedite multi-centre cancer research studies. More information on the OCREB and how it works can be found at: http://oicr.on.ca/oicr-programs-and-platforms/ontario-cancerresearch-ethics-board/terms-reference. ${ }^{8}$

\section{Relevant Literature}

\section{Consent}

The Canadian Standards Association (CSA) Model Code for the Protection of Personal Information (CAN/CSA-Q830) states that consent is required for the collection of personal information and its subsequent use or disclosure. ${ }^{9}$ CAN/CSA-Q830 was prepared by the CSA Technical Committee on Privacy, under the jurisdiction of the CSA Steering Committee on Business Management Systems, and was formally approved by these Committees. It has been approved as a National Standard of Canada by the Standards Council of Canada, and the key elements from the Standard were incorporated into the Personal Information Protection and Electronic Documents Act (PIPEDA) which is one part of Canada's national privacy legislation. CAN/CSA-Q830 lists ten topics that require special consideration (referred to as "Principles"): Accountability; Identifying Purposes; Consent; Limiting Collection; Limiting Use, Disclosure, and Retention; Accuracy, Safeguards, Openness, Individual Access, and Challenging Compliance. The Quebec Myotonic Dystrophy Registry compared registry privacy needs with CAN/CSA-Q830 and found them to be compatible. The authors recommended that the principles of the standard be considered during registry design and implementation. ${ }^{10}$
Considerable discussion has arisen around the issue of obtaining consent for registries and its potential impact on registry viability, comprehensiveness and data quality. The CAN/CSA-Q830 unequivocally states that consent is required for the collection of personal information and its subsequent use or disclosure. Additionally for the purpose of registries, consent is also likely to be required for projects where there will be direct patient contact or where genetic information will be collected and/or linked. ${ }^{11}$ CAN/CSA-Q830 does indicate that in some medical circumstances it may be inappropriate to obtain consent (individual is a minor; individual is seriously ill or mentally incapacitated; or, when seeking consent is otherwise impractical). ${ }^{9}$ However, CAN/CSA-Q830 states that in such circumstances while it is possible to collect information without consent, consent must be obtained in the event that the information is disclosed. According to CAN/CSA-Q830 consent must only be obtained from an individual after they have been informed of the purposes for which the collected information will be used and that organizations must not collect, use or disclose information beyond what is needed to fulfill the clearly outlined and legitimate purpose for which the information was collected. ${ }^{9}$ It holds that express consent should be sought when information is likely considered sensitive and cautions that many types of information can be sensitive within a given context. ${ }^{9}$ The standard is clear that consent can be given by an authorized representative including legal guardians and parents for minors. CAN/CSA-Q830 does not require that consent be given in writing. ${ }^{9}$ Methods of consent that are considered acceptable under the standard include: ${ }^{9}$

a) An application form that collects information and informs the individual of the potential use and/or disclosure of the information if it features a signature from the individual. By completing and signing the form an individual is considered to have provided consent.

b) A check-box may be used to allow individuals to request that their names and addresses not be given to other organizations. Individuals who do not check the box are assumed to have consented to the transmission of their information to third parties.

c) Consent may be given orally when information is collected over the telephone.

d) Consent may be given at the time that individuals use a product or service.

CAN/CSA-Q830 makes it clear that an individual may withdraw consent at any time subject to legal or contractual restrictions and reasonable notice. ${ }^{9}$ The individual must also be informed by the organization of the implications of the withdrawal. ${ }^{9}$

With respect to obtaining consent, consideration of who will approach the patient must be made. In one study, approach rates to obtain informed consent were lower when lists of eligible patients could not be obtained from hospital records or if coordinators could not approach patients without a physician first approaching them; however, none of the differences found in consent rates were statistically significant. ${ }^{11}$

A clear majority of REBs in Canada feel that patient consent should be required for registries and indeed support for patient 
consent is almost unanimous if the registry involves banking of biological samples or biomarkers (biobanking). ${ }^{12}$ While consent is required, a little over $50 \%$ of the REBs felt that the consent could run for the duration of the registry provided that significant change did not occur and a clear majority of the REBs agreed with this if the option to withdraw was also present. ${ }^{12}$

In addition to the Canadian literature examined above, a total of 15 American, 6 United Kingdom, and 5 other country full text documents were reviewed. One paper commented that the World Health Organization standard for clinical trial registries does not include the need for informed consent. ${ }^{13}$ However, it was felt that the inclusion of informed consent would significantly increase public confidence in clinical research and the manner in which clinical trials are conducted. ${ }^{13}$ In some cases consent was required by legislation. ${ }^{14-16}$ In one study an opt-out method for obtaining consent was utilized after a change in relevant legislation required consent and only $4 \%$ of patients opted out of the registry after receiving notice of the inclusion of their information in it. ${ }^{14}$ Another study found that requiring consent reduced participation and suggested an opt-out method was preferred to reduce bias introduced by the consent requirement. ${ }^{16}$ One registry used an electronic consent form that had to be completed before enrolling in an internet-based database..$^{17}$

\section{Privacy}

Registries may raise concerns on the part of participants and healthcare practitioners with respect to the security and privacy of registry data. In 2008, a Canadian Internet Use Survey by Statistics Canada found that $74 \%$ of Canadians were concerned or very concerned about privacy on the internet. ${ }^{18}$ This finding could be of particular concern to registries collecting data over the internet. It is important, though, not to overstate the extent of privacy concerns. One study found that concerns about internet privacy did not affect participant willingness to register in a database over the internet after $88 \%$ of registrants used this method. ${ }^{17}$ One study found that individuals registering over the internet were significantly younger than those registering through a call centre. ${ }^{17}$ As such, privacy concerns in solely electronic registries may introduce an age-selection bias.

Privacy can be viewed as both an objective inherent value desired by registry participants as well as a qualitative condition that describes access to or knowledge of thoughts, opinions, behaviors, and personal property. ${ }^{19}$ Research participants freely making their decision to participate in a research registry do so notwithstanding the risk arising from stigma associated with being identified as having a disease, discrimination by insurance companies or employers, and causing fear or distress to family members. ${ }^{19}$ Clear communication of the benefits that registries afford and the safeguards being employed may help to alleviate participant privacy concerns. ${ }^{19}$ Establishing trust by putting in place robust methods to prevent confidentiality breaches is fundamental to ensuring long-term participation. ${ }^{20}$

Privacy may be of particular concern for patients with a stigmatizing health condition. ${ }^{5}$ Inappropriate access to registry data could lead to the misuse of the information the registry contains and ultimately harm the registry participants. ${ }^{5}$ It is important to discuss administrative, physical and technical data safeguards with participants as a part of the informed consent process. ${ }^{5}$
Privacy legislation and ethics committee guidelines that require consent for patients to join registries may hinder the ability of rare disease registries to collect unbiased data. ${ }^{21}$ This risk can be ameliorated by procedures that ensure security and of the data, which may improve consent rates by reassuring participants that their data will be safe. Data confidentiality should be reconsidered each time data is used. ${ }^{10}$

In considering recruitment strategies, the involvement of patient organizations in advertising the registry may assist the protection of patient privacy during recruitment ${ }^{21}$ by enabling the notification of all patients involved with the patient organization about the registry including those patients could not otherwise be contacted by the registry team or may be unknown to the registry team. All research recruitment strategies should ensure that the trust of the participant is not abused, and protect them against over-solicitation. ${ }^{10}$

\section{Registry Design}

There was agreement in the international literature that policies and procedures around data collection, data access, and maintaining privacy should be developed and approved by local ethics review boards, ${ }^{5,22-24}$ In one jurisdiction it was suggested that generic policies might not be sufficient to protect data from being disclosed for legal purposes (e.g. subpoena) leading to a recommendation that specific access policies be created to ensure that registry data cannot be subpoenaed. ${ }^{24}$ It was also suggested that registry data on participating physicians should be protected from disclosure. ${ }^{24}$ Another report recommended privacy auditing by independent privacy consultants, training of registry staff about privacy and confidentiality, and obtaining signed confidentiality agreements from staff and contractors..$^{22}$ In this registry, background checks were conducted on staff. ${ }^{22}$

Registries should clearly identify in their management policies who is accountable from an organizational standpoint for data. This individual should be accessible for those who wish to request information or submit complaints ${ }^{10}$.

Both the amount and type of personal information collected by an organization should be limited to what is necessary to fulfill the purposes of the registry. ${ }^{10} \mathrm{CAN} / \mathrm{CSA}-\mathrm{Q} 830$ indicates that any information collected should be obtained with informed consent and that information handling policies and practices should be publicly available in accordance with the principle of "Openness" outlined in the standard.

Security safeguards protecting information contained within registries are to prevent loss, theft and unauthorized access, disclosure, copying, use or modification. ${ }^{10}$ CAN/CSA-Q830 states that the safeguards used should be appropriate for the sensitivity and amount of information being collected, how it will be distributed, and the format and method of storage. The greater the sensitivity of the information, the higher the level of protection required.

CAN/CSA-Q830 holds that guidelines and procedures should be developed regarding the retention of personal information for any given purpose. These guidelines should include minimum and maximum retention periods. Information that is no longer required to fulfill the purposes outlined by the organization collecting the data should be destroyed, erased or made anonymous. Procedures and policies for the destruction of personal information must be developed. Personal information 
contained within registries that have fulfilled their purpose, lack funding, are ineffective for research purposes, or otherwise are not operational should be destroyed.${ }^{10}$ Anonymization or pseudoanonymization through coding should be used to ensure confidentiality. This coding approach should be explained to participants. ${ }^{21}$

The use of custom-designed software applications with encrypted data exchange and firewall protection was advocated. ${ }^{23}$ Anonymizing data whenever possible was recommended. ${ }^{25}$

Researchers should receive data with encrypted patient identification (ID) numbers in order to ensure that ID numbers cannot be used to link data within the registry for unauthorized purposes. $^{22}$ Registry data, when used for research, should be released only to investigators who have obtained ethics approval for their research. ${ }^{25}$ Documentation of registry data release procedures and the process for reviewing requests should be developed. ${ }^{26}$ Subgroups of less than six individuals may be considered identifiable and excluded from data release procedures and processes for this reason. ${ }^{5}$

Data servers should be housed in a physically secure location

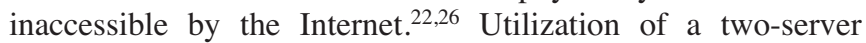
model where one server stores patient identifiers and a second server stores health information has been recommended. ${ }^{22,27}$ Electronic data access should be controlled by confidential passwords. ${ }^{2,23,25,26}$ Additionally, since electronic filing is more secure than hard copy filing, files should be backed up electronically and hard copies destroyed. ${ }^{22}$ The use of a dataviewing tracking system within registry software can enhance the protection of privacy. $5,23,26$

It is important to consider data linkage during the inception of a registry and to incorporate potential or actual data linkage plans into the informed consent process. ${ }^{5}$ Privacy and confidentiality are especially important to consider as when linking datasets one may be able to infer the identity of a patient in a linked database even after de-identification of the patients in the database. ${ }^{5}$ Data de-identification could involve coding data using a unique identifier; removing certain data elements and/or a statistical assessment of low probability of patient identification using the dataset..$^{5}$ More information on data security practices and mitigation of risks associated with data linkage will be provided in the Data Storage and Curation and Linkage sections of this guideline document.

\section{Other Considerations}

\section{Informed Consent Process}

In general, mandatory participation or inclusion in registries is not consistent with Canadian law. In most circumstances, a registry must obtain participant consent in a free and voluntary manner. Care must be paid to the potential influence of family members or the person obtaining consent within the consent process. Additionally, during the consent process participants must be given an appropriate amount of time to reflect. In some cases, it may be possible to apply for a waiver of consent especially where the neurological condition carries significant risk of death and/or population-based statistics are required; however, such waivers must be applied for in each applicable jurisdiction in which the registry operates.
With respect to registries, there are three important considerations with respect to informed consent: consent to creation of the registry using patient data, consent to the initial research purpose and use of registry data, and consent to subsequent use of data by the developers or others. ${ }^{5}$ It is important to note that additional consents may be needed for each unique research purpose..$^{5,7}$

In most cases, registries should confirm participant consent on an ongoing basis.

\section{Capacity to Consent}

For certain neurological conditions, the issue of capacity to consent not infrequently arises. A number of the diseases that could be considered for a registry may affect children who are minors and unable to provide informed consent under Canadian law. Among adults with progressive neurological diseases, the ability to provide informed consent may have been lost when the person is initially approached or could be lost during the course of the illness after recruitment. Assessment of capacity to consent to participate in a research study always requires careful consideration. Legal competence is a necessary aspect of free and informed consent. ${ }^{5}$ Due to the progressive nature of many neurological conditions it may be important to designate a substitute decision maker depending on project duration. The substitute decision maker could be an authorized representative such as a legal guardian, parent, or an individual named as the person's agent in an advanced (or personal) directive. ${ }^{7,9}$ This ensures that registry data could still be collected even if the patient loses the capacity to provide consent either permanently or on an intermittent basis as long as their substitute decision maker concurs. It is essential to address issues related to capacity to consent during initial registry design.

According to the TCPS- $2,{ }^{7}$ those who lack capacity to consent should neither be excluded from participation nor have their lack of capacity used to unfairly influence their participation. Typically, decisions regarding consent are authorized by a substitute decision maker, who is a person with legal authority to make decisions on an individual's behalf. It is, nevertheless, important for those who lack capacity to consent to remain as involved as possible in the decision about whether or not to participate. $^{7}$

The participation of minors in long-term registries also presents ethical concerns. While parents may consent for their children to participate for altruistic reasons, it is possible that a minor's participation in a registry could lead to adverse outcomes such as exclusion from educational opportunities and social programs. ${ }^{5}$ Over the course of the project, children may reach the age of majority and/ or otherwise develop the capacity to consent. Thus, procedures must be in place to ensure the renewed consent of registry participants who were recruited as minors and reach the age of majority.

Although non-competent individuals by definition lack the capacity to consent, every effort must be made to ascertain and respect their wishes. ${ }^{7}$ Hence, in addition to seeking consent from a substitute decision maker, a best practice would be to also seek assent from the non-competent individual. This assent could by sought by means of an assent form appropriate to the level of comprehension possessed by the individual. If the assent cannot be obtained in writing, oral assent should be sought and 
documented. ${ }^{7}$ It is important to emphasize that assent by the noncompetent individual should occur in addition to the informed consent process. ${ }^{7}$

\section{Withdrawal}

While participants have the right to withdraw their consent to participate in the registry overall at any time, registry design may prevent them from withdrawing data or biological materials they have already contributed. For example, if the registry anonymizes participant's biological samples, it may be impossible to destroy them once a withdrawal is received. If the registry is designed in a way that does not permit a participant to withdraw all of their data or biological materials, this limitation to their ability to withdraw and the nature of what will happen to such retained data should be clearly communicated during the informed consent process. ${ }^{5,7}$ It is also important that the procedure for withdrawal be clearly communicated to participants during the informed consent process. .,7 $^{5,7}$

\section{Research Involving Aboriginal People and Communities}

This document uses the term "Aboriginal" to refer to all Canadian people of First Nations, Métis or Inuit descent.

Most of the research conducted in Aboriginal populations has historically been conducted by non-Aboriginal groups with external interests. ${ }^{7,28}$ As a result, the content of research and the approach to research design and methodology has not generally reflected Aboriginal views. ${ }^{7,28}$ Not only have Aboriginal people tended not to benefit from these research activities, ${ }^{7}$ but in some cases the outcomes of research have been harmful to Aboriginal people and communities. ${ }^{28}$ Given this history, Aboriginal communities tend to be wary of external research and researchers. ${ }^{28}$ Therefore, it is particularly important for those developing registries to be aware of the unique considerations that arise if an Aboriginal community is to become involved in a registry project and to work with the community in an ethical and respectful manner., ${ }^{7,30}$ It is strongly recommended that Aboriginal community members be involved in the design and implementation of the registry if at all possible. . $28,29,31,32^{2}$

Chapter 9 of theTCPS-2 is dedicated to research involving First Nations, Inuit and Métis peoples of Canada. ${ }^{7}$ The Canadian Institutes of Health Research (CIHR) use this chapter as its policy with respect to research involving Aboriginal communities. ${ }^{29}$ The same principles of Respect for Persons, Concern for Welfare and Justice apply when conducting research on Aboriginal people or in Aboriginal communities. ${ }^{7}$ The TCPS2 acknowledges the unique status, cultural values and traditions of Aboriginal people and has established additional guidelines for how to conduct research in an ethical manner. ${ }^{7}$

Community engagement at all stages is essential for research conducted in Aboriginal communities. ${ }^{7,28,30}$ Additionally, formal research agreements should be established; research should be conducted, interpreted and disseminated in collaboration with communities and their representatives; and, research should be relevant to community priorities and generally be of benefit to the communities. $7,28,30,31,33$ Elders and other knowledge holders play important roles in Aboriginal communities and must be acknowledged and respected by researchers.,28,30 Of particular relevance to registries is the requirement that an institutional
REB review take place for linkage of anonymous data sets or data associated with biological materials. ${ }^{7}$

During the initial planning stages, it may be necessary for researchers to obtain permission from territorial/regional licensing agencies in some jurisdictions, in addition to obtaining permission from community authorities/representatives. ${ }^{34}$ In Nunavut and the Northwest Territories, researchers must have a license to do research: both territories have research institutes that can assist with licensing. ${ }^{31,32,35}$ The licensing process involves submitting a proposal that describes, in plain language, the research question and methodology. ${ }^{31,34}$ Conditions of the license include notifying the appropriate authority of any changes to the information about the study, and the production of a report six months after the license expires. ${ }^{34}$ For a long term project, it may be necessary to have a license extended or renewed.$^{34}$ It is important to note that research being conducting in multiple Aboriginal communities may require licenses from each of the communities and/or jurisdictions. ${ }^{31,34}$ Additionally, multidisciplinary research projects may require permits from several different agencies. ${ }^{31}$

Cultural and language barriers may impede the informed consent process. ${ }^{36}$ It is important to consider local languages during all stages of research. ${ }^{28,30-32}$ This might involve translating materials such as informed consent forms and interview questions. ${ }^{32}$ Producing research summaries in local languages is recommended. ${ }^{30}$ The Nunavut Interpreter/Translator Society is one organization that may be able to assist with translation. ${ }^{35}$ Literacy may also be an issue with respect to written consent because not all languages are written and not all people can read written languages..$^{32,33}$ To address this, researchers may want to consider a verbal consent option and keep a written record of the verbal consent process. ${ }^{32,33}$

When recruiting participants into a registry, it is important to consider differences in the age of majority in different Aboriginal communities. Those who have not reached the age of majority lack the capacity to give informed consent. ${ }^{7}$ In Nunavut, the Northwest Territories and the Yukon the age of majority is 19 while in other areas of Canada the age may be 18 or 19 depending on the province.

One important issue with respect to consent is the misconception held by some Aboriginal people that refusing to participate in government funded research will result in a loss of government funding and resources to the region. ${ }^{28}$ Hence, it is especially important to insure that consent is given freely and with appropriate knowledge of the research project. ${ }^{7,28}$ Ethical Principles for the Conduct of Research in the North published by the Association of Canadian Universities for Northern Studies describes the importance of free, informed and ongoing consent and establishes a model consent process which aligns with TCPS-2 guidelines for research involving Aboriginal people..$^{7,30}$ Additionally, as a part of ongoing consent, it is recommended that researchers provide explanations of research objectives, methods, and results to the communities in which they do research. ${ }^{28,30}$

\section{Languages}

It may be necessary to ensure that consent forms and other relevant materials are available in languages other than English and French in order to ensure a representative sample is gathered 
Table 1: Intellectual Property and Ownership Considerations by Province [1]

\begin{tabular}{|c|c|c|c|c|c|c|}
\hline PROVINCE & $\begin{array}{l}\text { Who is responsible } \\
\text { for health } \\
\text { information data }\end{array}$ & $\begin{array}{l}\text { Who can store } \\
\text { health } \\
\text { information } \\
\text { data }\end{array}$ & $\begin{array}{l}\text { How long can } \\
\text { identified health } \\
\text { information be } \\
\text { stored? }\end{array}$ & $\begin{array}{l}\text { Can identified health } \\
\text { information be } \\
\text { transferred to another } \\
\text { location for additional } \\
\text { storage duration }\end{array}$ & $\begin{array}{l}\text { What formats are used to store } \\
\text { health information? }\end{array}$ & $\begin{array}{l}\text { How long must } \\
\text { researchers store data } \\
\text { once a study is closed? }\end{array}$ \\
\hline $\begin{array}{l}\text { Alberta } \\
\text { Health Information Act } \\
\text { http://www.qp.alberta.ca/57 } \\
\text { 4.cfm?page=H05.cfm\&leg_ty } \\
\text { pe=Acts\&isbncln=97807797 } \\
\underline{52607}\end{array}$ & $\begin{array}{l}\text { Custodians, as } \\
\text { defined by the } \\
\text { Health Information } \\
\text { Act, have custody } \\
\text { and control of health } \\
\text { information. } \\
\text { Custodians may be } \\
\text { individual health } \\
\text { professionals; health } \\
\text { facilities or the } \\
\text { provincial health } \\
\text { board. Health } \\
\text { information includes } \\
\text { diagnostic } \\
\text { information; } \\
\text { information about } \\
\text { treatment or care; } \\
\text { information about } \\
\text { health service } \\
\text { providers and } \\
\text { registration } \\
\text { information. }\end{array}$ & $\begin{array}{l}\text { According to the } \\
\text { Health } \\
\text { Information Act, } \\
\text { custodians, } \\
\text { information } \\
\text { managers, and } \\
\text { researchers who } \\
\text { enter into } \\
\text { agreements with } \\
\text { custodians can } \\
\text { store health } \\
\text { information data. }\end{array}$ & $\begin{array}{l}\text { This is not specified } \\
\text { in the Health } \\
\text { Information Act, but } \\
\text { the researcher is } \\
\text { obligated to adhere } \\
\text { to conditions set out } \\
\text { by the custodian and } \\
\text { any relevant ethics } \\
\text { committee relating to } \\
\text { the use, protection, } \\
\text { disclosure or disposal } \\
\text { of health information } \\
\text { (Health Information } \\
\text { Act: Section } \\
54(1) \text { (a) (ii)) } \\
\text { When custodians, } \\
\text { disclose health } \\
\text { information, they } \\
\text { must make a record } \\
\text { as per section } 41 \text { and } \\
\text { retain that record of } \\
\text { disclosure for } 10 \\
\text { years following the } \\
\text { date of disclosure. }\end{array}$ & $\begin{array}{l}\text { This is not specified in the } \\
\text { Health Information Act, } \\
\text { but the researcher is } \\
\text { obligated to adhere to } \\
\text { conditions set out by the } \\
\text { custodian and any relevant } \\
\text { ethics committee relating } \\
\text { to the use, protection, } \\
\text { disclosure or disposal of } \\
\text { health information (Health } \\
\text { Information Act: Section } \\
\text { 54(1)(a)(ii)) }\end{array}$ & $\begin{array}{l}\text { According to the Health } \\
\text { Information Act, "record" means } \\
\text { a record of health information in } \\
\text { any form } \\
\text { and includes notes, images, } \\
\text { audiovisual recordings, } \\
\text { x-rays, books, documents, maps, } \\
\text { drawings, photographs, } \\
\text { letters, vouchers and papers and } \\
\text { any other information } \\
\text { that is written, photographed, } \\
\text { recorded or stored in any } \\
\text { manner, but does not include } \\
\text { software or any mechanism } \\
\text { that produces records. } \\
\text { Regardless of the format of the } \\
\text { record, the establishment of } \\
\text { safeguards is required. (Health } \\
\text { Information Act) }\end{array}$ & $\begin{array}{l}\text { This is not specified in } \\
\text { the Health Information } \\
\text { Act, but the researcher is } \\
\text { obligated to adhere to } \\
\text { conditions set out by the } \\
\text { custodian and any } \\
\text { relevant ethics committee } \\
\text { relating to the use, } \\
\text { protection, disclosure or } \\
\text { disposal of health } \\
\text { information (Health } \\
\text { Information Act: Section } \\
54(1)(a)(i i)) \\
\text { When custodians, } \\
\text { disclose health } \\
\text { information, they must } \\
\text { make a record as per } \\
\text { section } 41 \text { and retain that } \\
\text { record of disclosure for } \\
10 \text { years following the } \\
\text { date of disclosure. }\end{array}$ \\
\hline $\begin{array}{l}\text { British Columbia } \\
\text { Freedom of Information and } \\
\text { Protection of Privacy Act } \\
\text { (FIPPA) } \\
\text { http://www.oipc.bc.ca/legisl } \\
\text { ation/FIPPA/Freedom_of_I } \\
\text { nformation_and_Protection } \\
\text { of_Privacy_Act } \% 28 \text { April } \% 20 \\
2010 \% 29 . \text { htm } \\
\text { Personal Health Information } \\
\text { Access and Protection of } \\
\text { Privacy Act (e-Health Act) } \\
\text { http://www.bclaws.ca/EPLi } \\
\text { braries/bclaws_new/docume } \\
\text { nt/ID/freeside/00_08038_01 } \\
\text { Personal Information and } \\
\text { Protection Act (PIPA) } \\
\text { http://www.oipc.bc.ca/legisl } \\
\frac{\text { ation/PIPA/PIPA } \% 282006}{\% 29 . p d f}\end{array}$ & $\begin{array}{l}\text { Ministry of Health, } \\
\text { health authorities and } \\
\text { Population Data BC } \\
\text { per the provisions of } \\
\text { the Freedom of } \\
\text { Information and } \\
\text { Protection of Privacy } \\
\text { Act (FIPPA) and the } \\
\text { Personal Health } \\
\text { Information Access } \\
\text { and Protection of } \\
\text { Privacy Act (e-Health } \\
\text { Act). Health } \\
\text { professionals in } \\
\text { private practice are } \\
\text { subject to the } \\
\text { Personal Information } \\
\text { and Protection Act } \\
\text { (PIPA). }\end{array}$ & $\begin{array}{l}\text { Ministry of } \\
\text { Health } \\
\text { health authorities, } \\
\text { and } \\
\text { Population Data } \\
\text { BC under FIPPA. } \\
\text { Health } \\
\text { professionals in } \\
\text { private practice } \\
\text { are subject to } \\
\text { PIPA. }\end{array}$ & $\begin{array}{l}\text { According to the } \\
\text { FIPPA Act and the } \\
\text { Personal Health } \\
\text { Information Access } \\
\text { and Protection of } \\
\text { Privacy Act, data can } \\
\text { be stored as long as it } \\
\text { is needed for the } \\
\text { purpose for which it } \\
\text { was collected. When } \\
\text { the information is no } \\
\text { longer needed for the } \\
\text { purposes for which it } \\
\text { was collected it } \\
\text { should be destroyed } \\
\text { or at a minimum de- } \\
\text { identified and in } \\
\text { accordance with } \\
\text { institutional policies } \\
\text { and legislation, the } \\
\text { stipulations of the } \\
\text { data sharing } \\
\text { agreement; data } \\
\text { stewardship } \\
\text { committee, or other } \\
\text { appropriate } \\
\text { institutional policies } \\
\text { or safeguards. }\end{array}$ & $\begin{array}{l}\text { FIPPA and the e-Health } \\
\text { Act prohibit the disclosure } \\
\text { of personal identifiable } \\
\text { information outside of } \\
\text { Canada as well as access to } \\
\text { such records from outside } \\
\text { Canada except in the } \\
\text { presence of explicit } \\
\text { consent. An amendment } \\
\text { to FIPPA in } 2006 \text { relaxed } \\
\text { these constraints } \\
\text { somewhat with respect to } \\
\text { out of country data system } \\
\text { management and data } \\
\text { recovery but with the } \\
\text { following strict conditions: } \\
\text { access must be necessary; } \\
\text { should be granted only for } \\
\text { the minimum period } \\
\text { required; and must be } \\
\text { controlled and secure. } \\
\text { According to the e-Health } \\
\text { Act, when data are } \\
\text { disclosed for research, } \\
\text { researchers must enter into } \\
\text { an information sharing } \\
\text { agreement and adhere to } \\
\text { its terms. }\end{array}$ & $\begin{array}{l}\text { According to the FIPPA act, a } \\
\text { "record" includes books, } \\
\text { documents, maps, drawings, } \\
\text { photographs, letters, vouchers, } \\
\text { papers and any other thing on } \\
\text { which information is recorded or } \\
\text { stored by graphic, electronic, } \\
\text { mechanical or other means, but } \\
\text { does not include a computer } \\
\text { program or any other mechanism } \\
\text { that produces records. BC } \\
\text { legislation (FIPPA and the e- } \\
\text { Health Act) also define "Health } \\
\text { Information Banks" which are } \\
\text { electronic repositories of health } \\
\text { information. } \\
\text { Under both FIPPA and PIPA } \\
\text { regardless of the format of the } \\
\text { record, the establishment of } \\
\text { safeguards to prevent } \\
\text { unauthorized use, disclosure, } \\
\text { disposal, and access including } \\
\text { copying and modification is } \\
\text { required. }\end{array}$ & $\begin{array}{l}\text { According to the FIPPA } \\
\text { Act and PIPA, } \\
\text { information collectors } \\
\text { must retain personal } \\
\text { information for one year } \\
\text { if it is used to make a } \\
\text { decision directly affecting } \\
\text { the individual. PIPA } \\
\text { further stipulates that } \\
\text { collected personal } \\
\text { information must be } \\
\text { destroyed when the } \\
\text { purpose for the collection } \\
\text { of the information is no } \\
\text { longer being served, } \\
\text { and/or the information is } \\
\text { no longer required for } \\
\text { business or legal } \\
\text { purposes. Researchers } \\
\text { must also adhere to } \\
\text { retention periods that are } \\
\text { established by tax } \\
\text { legislation and } \\
\text { institutional records } \\
\text { retention and disposition } \\
\text { schedules. }\end{array}$ \\
\hline
\end{tabular}

from multi-ethnic populations. . $^{511}$ When translating materials, it is important to ensure that the translation is not only accurate, but linguistically and culturally appropriate. ${ }^{5}$ A best practice would be to use a certified translation service to translate materials and/or to have a qualified interpreter attend the informed consent process. ${ }^{5}$ An alternative might be to engage community translators in a reverse translation activity for the purposes of verifying the accuracy of the translation. Overall, consent documents must be written in plain language, and the literacy level of the target population should be considered. ${ }^{7}$ Individual ethics boards may also have specific requirements about the reading comprehension level of informed consent documents.

\section{Biobanks}

In order to establish a biobank (a large collection of tissue samples brought together for use in research), REB review is necessary. ${ }^{7}$ The different nature of a biobank and a genetic research database should be noted. ${ }^{37}$ While the terms are often used synonymously, a genetic research database contains information on the genetic characteristics of registered individuals while a biobank will contain samples of tissue or blood from registered individuals which may or may not give rise to genetic information stored within the biobank. Biobanks are commonly linked with other health record information 
Table 1: Intellectual Property and Ownership Considerations by Province [continued 2]

\begin{tabular}{|c|c|c|c|c|c|c|}
\hline PROVINCE & $\begin{array}{l}\text { Who is responsible } \\
\text { for health } \\
\text { information data }\end{array}$ & $\begin{array}{l}\text { Who can store } \\
\text { health } \\
\text { information } \\
\text { data }\end{array}$ & $\begin{array}{l}\text { How long can } \\
\text { identified health } \\
\text { information be } \\
\text { stored? }\end{array}$ & $\begin{array}{l}\text { Can identified health } \\
\text { information be } \\
\text { transferred to another } \\
\text { location for additional } \\
\text { storage duration }\end{array}$ & $\begin{array}{l}\text { What formats are used to store } \\
\text { health information? }\end{array}$ & $\begin{array}{l}\text { How long must } \\
\text { researchers store data } \\
\text { once a study is closed? }\end{array}$ \\
\hline $\begin{array}{l}\text { Manitoba } \\
\text { The Personal Health } \\
\text { Information Act } \\
\text { http://web2.gov.mb.ca/laws } \\
\text { /statutes/ccsm/_pdf.php?ca } \\
\mathrm{p}=\mathrm{p} 33.5\end{array}$ & $\begin{array}{l}\text { Trustees collect and } \\
\text { maintain personal } \\
\text { health information. } \\
\text { Trustees may include } \\
\text { health professionals; } \\
\text { health care } \\
\text { institutions; and } \\
\text { government } \\
\text { organizations } \\
\text { involved in } \\
\text { healthcare. }\end{array}$ & $\begin{array}{l}\text { Trustees, } \\
\text { information } \\
\text { managers, } \\
\text { researchers who } \\
\text { enter into } \\
\text { agreement with } \\
\text { trustees. } \\
\text { Information must } \\
\text { be stored in a } \\
\text { secure physical } \\
\text { location in an } \\
\text { electronically } \\
\text { secure manner } \\
\text { with appropriate } \\
\text { access safeguards. } \\
\text { Electronic or } \\
\text { manual logging of } \\
\text { access to data } \\
\text { must be kept. } \\
\text { Written security } \\
\text { policies and } \\
\text { procedures must } \\
\text { be in place. } \\
\text { Security } \\
\text { safeguards must } \\
\text { be audited at least } \\
\text { every two years. }\end{array}$ & $\begin{array}{l}\text { As long as is } \\
\text { permitted under the } \\
\text { institution's written } \\
\text { records retention and } \\
\text { destruction policy } \\
\text { which is required } \\
\text { under the Act. } \\
\text { Compliance with } \\
\text { other rules regarding } \\
\text { retention and } \\
\text { destruction of } \\
\text { records may be } \\
\text { required if the trustee } \\
\text { is a public body. }\end{array}$ & $\begin{array}{l}\text { Not specified in the } \\
\text { Personal Health } \\
\text { Information Act, however, } \\
\text { trustees must enter into } \\
\text { written agreement when } \\
\text { information is shared with } \\
\text { information managers and } \\
\text { researchers. Information } \\
\text { managers and researchers } \\
\text { would be subject to the } \\
\text { terms specified in the } \\
\text { agreement. }\end{array}$ & $\begin{array}{l}\text { The Personal Health Information } \\
\text { Act defines "record" or "recorded } \\
\text { information" as a record of } \\
\text { information in any form, and } \\
\text { includes } \\
\text { information that is written, } \\
\text { photographed, recorded } \\
\text { or stored in any manner, on any } \\
\text { storage medium or } \\
\text { by any means, including by } \\
\text { graphic, electronic or } \\
\text { mechanical means, but does not } \\
\text { include electronic } \\
\text { software or any mechanism that } \\
\text { produces records; } \\
\text { Removable media must be } \\
\text { physically secured. }\end{array}$ & $\begin{array}{l}\text { Records of user activity } \\
\text { with respect to the data } \\
\text { must be retained for a } \\
\text { minimum of } 3 \text { years. User } \\
\text { activity records must also } \\
\text { be audited at least once } \\
\text { prior to destruction. A } \\
\text { written policy regarding } \\
\text { storage and destruction of } \\
\text { health information must } \\
\text { be in place and must be } \\
\text { complied with. This } \\
\text { policy must not violate } \\
\text { rules around retention and } \\
\text { destruction of records of } \\
\text { public bodies if the trustee } \\
\text { is a public body. } \\
\text { Trustees must enter into } \\
\text { written agreement when } \\
\text { information is shared with } \\
\text { information managers and } \\
\text { researchers. Information } \\
\text { managers and researchers } \\
\text { would be subject to the } \\
\text { terms specified in the } \\
\text { agreement. }\end{array}$ \\
\hline $\begin{array}{l}\text { New Brunswick } \\
\text { The Personal Health } \\
\text { Information Privacy and } \\
\text { Access Act } \\
\text { http://www.gnb.ca/0062/P } \\
\text { DF-acts/p-07-05.pdf }\end{array}$ & $\begin{array}{l}\text { Custodians collect } \\
\text { and maintain } \\
\text { personal health } \\
\text { information. } \\
\text { Custodians could } \\
\text { include health } \\
\text { professionals; health } \\
\text { institutions; health } \\
\text { service organizations; } \\
\text { public bodies; } \\
\text { researchers or other } \\
\text { designated parties. }\end{array}$ & $\begin{array}{l}\text { Custodians, } \\
\text { agents, } \\
\text { information } \\
\text { managers, } \\
\text { researchers who } \\
\text { enter into } \\
\text { agreements with } \\
\text { custodians. } \\
\text { Custodians and } \\
\text { their agents must } \\
\text { have written } \\
\text { documentation } \\
\text { outlining } \\
\text { safeguards in } \\
\text { place to protect } \\
\text { data and activities } \\
\text { undertaken in the } \\
\text { event of a breach. } \\
\text { Breaches must be } \\
\text { logged and } \\
\text { follow-up } \\
\text { mitigation of } \\
\text { future risk must } \\
\text { be documented. } \\
\text { Agreements with } \\
\text { information } \\
\text { managers must } \\
\text { outline safeguards } \\
\text { employed by the } \\
\text { information } \\
\text { manager with } \\
\text { respect to the } \\
\text { information. }\end{array}$ & $\begin{array}{l}\text { Information that is } \\
\text { more than } 100 \text { years } \\
\text { old is not subject to } \\
\text { the Act. } \\
\text { Additionally, if } 50 \\
\text { years or more have } \\
\text { elapsed since the } \\
\text { death of the } \\
\text { individual that the } \\
\text { information pertains } \\
\text { to, it is not subject to } \\
\text { the Act. } \\
\text { However, custodians } \\
\text { must set and adhere } \\
\text { to written policy } \\
\text { regarding archival } \\
\text { storage, access and } \\
\text { secure destruction of } \\
\text { personal health } \\
\text { information as per } \\
\text { Section } 55(1) \text {. }\end{array}$ & $\begin{array}{l}\text { If the transfer will involve } \\
\text { disclosure of the } \\
\text { information to a party } \\
\text { outside of New Brunswick } \\
\text { or for the purposes of } \\
\text { research, express consent } \\
\text { from the relevant } \\
\text { individual is required. } \\
\text { Written or physical } \\
\text { disclosures without } \\
\text { consent must be noted. } \\
\text { Access to information } \\
\text { systems as the means of } \\
\text { disclosure need not be } \\
\text { noted, provided that } \\
\text { electronic logging of access } \\
\text { is in place. Disclosure } \\
\text { outside of the Province is } \\
\text { only permitted for the } \\
\text { purposes of securing } \\
\text { health care; health } \\
\text { programs or is limited to } \\
\text { registration information } \\
\text { only. Information } \\
\text { managers from outside the } \\
\text { province or outside } \\
\text { Canada are permitted } \\
\text { provided an appropriate } \\
\text { agreement is in place. }\end{array}$ & $\begin{array}{l}\text { The Personal Health Information } \\
\text { Privacy and Access Act defines } \\
\text { "record" as a record containing } \\
\text { information in any form, } \\
\text { including information that is oral, } \\
\text { written, photographed, recorded } \\
\text { or stored in any manner, on any } \\
\text { storage medium or by graphic, } \\
\text { electronic, mechanical or any } \\
\text { other means, but does not include } \\
\text { electronic software or any } \\
\text { mechanism that produces records. } \\
\text { Regardless of the format of the } \\
\text { record, the establishment of } \\
\text { safeguards is required. }\end{array}$ & $\begin{array}{l}\text { Records provided for the } \\
\text { purposes of research must } \\
\text { be destroyed or de- } \\
\text { identified at the earliest } \\
\text { opportunity consistent } \\
\text { with the purposes of the } \\
\text { project. }\end{array}$ \\
\hline
\end{tabular}

including disease characteristics, treatment options and patient personal data. Such linkage may give rise to unique privacy concerns where traditional methods of data de-identification may not be adequate given the unique characteristics provided by some genetic information alone or in combination with other medical or personal data. Genetic data should be treated as personal data and coded accordingly. ${ }^{37}$ There is also concern that biological information will be used not only to gather knowledge on the individual from whom the information was collected, but that the biological information will be used to infer knowledge about that individuals biological relatives. ${ }^{5}$ In addition, there is concern that biological information gathered by registries will be used against participants and their biological relatives in decisions about employment and life insurance. ${ }^{5}$ This is particularly a concern for conditions that can be predicted or diagnosed using genetic information. ${ }^{5}$ Given these concerns, it is 
Table 1: Intellectual Property and Ownership Considerations by Province [continued 3]

\begin{tabular}{|c|c|c|c|c|c|c|}
\hline PROVINCE & $\begin{array}{l}\text { Who is responsible } \\
\text { for health } \\
\text { information data }\end{array}$ & $\begin{array}{l}\text { Who can store } \\
\text { health } \\
\text { information } \\
\text { data }\end{array}$ & $\begin{array}{l}\text { How long can } \\
\text { identified health } \\
\text { information be } \\
\text { stored? }\end{array}$ & $\begin{array}{l}\text { Can identified health } \\
\text { information be } \\
\text { transferred to another } \\
\text { location for additional } \\
\text { storage duration }\end{array}$ & $\begin{array}{l}\text { What formats are used to store } \\
\text { health information? }\end{array}$ & $\begin{array}{c}\text { How long must } \\
\text { researchers store data } \\
\text { once a study is closed? }\end{array}$ \\
\hline $\begin{array}{l}\text { Newfoundland } \\
\text { Personal Health Information } \\
\text { Act } \\
\frac{\text { http://assembly.nl.ca/Legisla }}{\text { tion/sr/statutes/p07-01.htm }} \\
\text { Health Research Ethics } \\
\text { Authority } \\
\underline{\text { http://www.assembly.nl.ca/1 }} \\
\text { egislation/sr/statutes/h01- } \\
\text { 2.htm }\end{array}$ & $\begin{array}{l}\text { According to the } \\
\text { Personal Health } \\
\text { Information Act, } \\
\text { custodians have } \\
\text { custody and control } \\
\text { of health } \\
\text { information. } \\
\text { Custodians may } \\
\text { include healthcare } \\
\text { professionals or } \\
\text { providers; } \\
\text { administrators or } \\
\text { boards/committees } \\
\text { of health institutions; } \\
\text { and various faculties } \\
\text { and schools of } \\
\text { Memorial University } \\
\text { of Newfoundland. }\end{array}$ & $\begin{array}{l}\text { Custodians, } \\
\text { information } \\
\text { managers, and } \\
\text { researchers } \\
\text { whose project has } \\
\text { been approved by } \\
\text { the Health } \\
\text { Research Ethics } \\
\text { Authority. } \\
\text { Written policies } \\
\text { outlining data } \\
\text { safeguards } \\
\text { appropriate to the } \\
\text { type of storage, } \\
\text { location of } \\
\text { storage and } \\
\text { sensitivity of the } \\
\text { information must } \\
\text { be in place. } \\
\text { Information } \\
\text { managers } \\
\text { designated to } \\
\text { store or handle } \\
\text { health } \\
\text { information must } \\
\text { have a written } \\
\text { agreement with } \\
\text { the custodian in } \\
\text { place. }\end{array}$ & $\begin{array}{l}\text { Not specified in An } \\
\text { Act to Provide for } \\
\text { the Protection of } \\
\text { Personal Health } \\
\text { Information, but } \\
\text { agreements between } \\
\text { custodians and } \\
\text { information } \\
\text { managers must be } \\
\text { established. } \\
\text { Additionally, the } \\
\text { Health Research } \\
\text { Ethics Authority may } \\
\text { impose conditions } \\
\text { for approval for } \\
\text { researchers. }\end{array}$ & $\begin{array}{l}\text { Disclosure outside of the } \\
\text { province is permitted } \\
\text { provided that consent has } \\
\text { been obtained or that the } \\
\text { disclosure is for a purpose } \\
\text { permitted under the Act. } \\
\text { Written or physical } \\
\text { disclosures must be noted. } \\
\text { Access to information } \\
\text { systems as the means of } \\
\text { disclosure need not be } \\
\text { noted, provided that } \\
\text { electronic logging of access } \\
\text { is in place. }\end{array}$ & $\begin{array}{l}\text { According to the Personal Health } \\
\text { Information Act, a "record" is a } \\
\text { record of personal health } \\
\text { information in any form, and } \\
\text { includes personal health } \\
\text { information that is written, } \\
\text { photographed, recorded or stored } \\
\text { in any manner, but does not } \\
\text { include a computer program or a } \\
\text { mechanism that produces records } \\
\text { on a storage medium. } \\
\text { Regardless of the format of the } \\
\text { record, the establishment of } \\
\text { safeguards is required. }\end{array}$ & $\begin{array}{l}\text { Not specified in An Act } \\
\text { to Provide for the } \\
\text { Protection of Personal } \\
\text { Health Information, but } \\
\text { agreements between } \\
\text { custodians and } \\
\text { information managers } \\
\text { must be established. } \\
\text { Additionally, the Health } \\
\text { Research Ethics Authority } \\
\text { may impose conditions } \\
\text { for approval for } \\
\text { researchers }\end{array}$ \\
\hline $\begin{array}{l}\text { Northwest Territories } \\
\text { Access to Information and } \\
\text { Protection of Privacy Act } \\
\frac{\text { http://www.justice.gov.nt.ca }}{\text { Lpdf/ACTS/Access } \% 20 \text { to } \%} \\
\text { 20Information } \% 20 \text { and } \% 20 \mathrm{Pr} \\
\underline{\text { otection } \% 20 \text { of } \% 20 \text { Privacy.pd }} \\
\underline{f}\end{array}$ & $\begin{array}{l}\text { Public bodies that } \\
\text { collect and maintain } \\
\text { health information } \\
\text { are subject to the } \\
\text { Access to } \\
\text { Information and } \\
\text { Protection of Privacy } \\
\text { Act. }\end{array}$ & $\begin{array}{l}\text { Public bodies, } \\
\text { researchers who } \\
\text { enter into } \\
\text { agreements with } \\
\text { public bodies. }\end{array}$ & $\begin{array}{l}\text { According to the } \\
\text { Access to } \\
\text { Information and } \\
\text { Protection of Privacy } \\
\text { Act, the person to } \\
\text { whom the } \\
\text { information is } \\
\text { disclosed must sign a } \\
\text { formal agreement } \\
\text { and comply with its } \\
\text { conditions. } \\
\text { Conditions regarding } \\
\text { data safeguards, } \\
\text { destruction and de- } \\
\text { identification of data, } \\
\text { and further or } \\
\text { subsequent } \\
\text { disclosure may be } \\
\text { imposed by the } \\
\text { public body } \\
\text { disclosing the } \\
\text { information. }\end{array}$ & $\begin{array}{l}\text { Disclosure to the } \\
\text { Northwest Territories } \\
\text { Archives for the purposes } \\
\text { of archiving is permitted. } \\
\text { According to the Access to } \\
\text { Information and } \\
\text { Protection of Privacy Act, } \\
\text { the person to whom the } \\
\text { information is } \\
\text { disclosed must sign a } \\
\text { formal agreement and } \\
\text { comply with its conditions. }\end{array}$ & $\begin{array}{l}\text { According to the Access to } \\
\text { Information and Protection of } \\
\text { Privacy Act, a "record" is a record } \\
\text { of information in any form and } \\
\text { includes information that is } \\
\text { written, photographed, recorded } \\
\text { or stored in any manner, but does } \\
\text { not include } \\
\text { a computer program or other } \\
\text { mechanism that produces records. } \\
\text { Regardless of the format of the } \\
\text { record, the establishment of } \\
\text { safeguards is required. }\end{array}$ & $\begin{array}{l}\text { The Exceptions to } \\
\text { disclosures do not apply } \\
\text { to information that has } \\
\text { been in a record for more } \\
\text { than } 15 \text { years. } \\
\text { According to According } \\
\text { to the Access to } \\
\text { Information and } \\
\text { Protection of Privacy Act, } \\
\text { the person to whom the } \\
\text { information is disclosed } \\
\text { must sign a formal } \\
\text { agreement and comply } \\
\text { with its conditions. } \\
\text { Conditions regarding data } \\
\text { safeguards, destruction } \\
\text { and de-identification of } \\
\text { data, and further or } \\
\text { subsequent disclosure may } \\
\text { be imposed by the public } \\
\text { body disclosing the } \\
\text { information. }\end{array}$ \\
\hline
\end{tabular}

essential to store biological materials in appropriate facilities and in compliance with applicable standards and appropriate safeguards must be established to protect participants biological materials and, in turn, information about participants that can be obtained by their biological materials. ${ }^{7}$ Additionally, biobanks must institute sound and robust policies and procedures that are actively monitored. ${ }^{38}$

\section{Mandatory Reporting}

It is possible that information obtained during participation in a registry study may warrant further action on the part of the researchers/medical professionals. For example, the information collected may indicate that a patient diagnosed with Alzheimer's disease or another form of dementia is still driving a motor vehicle. Some Canadian provinces have mandatory reporting obligations on the part of physicians with respect to certain types of information. There are differences in applicable laws across provinces. If mandatory reporting of certain types of information may be required for public safety reasons, this should be disclosed to participants at the time of recruitment.

\section{Family Members}

Registries obtaining information on family members should consider privacy implications carefully and wherever possible obtain this information with consent or in a manner that does not 
Table 1: Intellectual Property and Ownership Considerations by Province [continued 4]

\begin{tabular}{|c|c|c|c|c|c|c|}
\hline PROVINCE & $\begin{array}{l}\text { Who is responsible } \\
\text { for health } \\
\text { information data }\end{array}$ & $\begin{array}{l}\text { Who can store } \\
\text { health } \\
\text { information } \\
\text { data }\end{array}$ & $\begin{array}{l}\text { How long can } \\
\text { identified health } \\
\text { information be } \\
\text { stored? }\end{array}$ & $\begin{array}{l}\text { Can identified health } \\
\text { information be } \\
\text { transferred to another } \\
\text { location for additional } \\
\text { storage duration }\end{array}$ & $\begin{array}{l}\text { What formats are used to store } \\
\text { health information? }\end{array}$ & $\begin{array}{c}\text { How long must } \\
\text { researchers store data } \\
\text { once a study is closed? }\end{array}$ \\
\hline $\begin{array}{l}\text { Nova Scotia } \\
\text { Personal Health Information } \\
\text { Act } \\
\frac{\text { https://www.gov.ns.ca/dhw/ }}{\text { phia/ }}\end{array}$ & $\begin{array}{l}\text { Custodians as } \\
\text { defined by the } \\
\text { Personal Health } \\
\text { Information Act. } \\
\text { This includes health } \\
\text { professionals or a } \\
\text { person operating a } \\
\text { group practice of } \\
\text { health professionals; } \\
\text { health authorities, } \\
\text { pharmacies and } \\
\text { continuing care } \\
\text { facilities. }\end{array}$ & $\begin{array}{l}\text { Custodians and } \\
\text { researchers who } \\
\text { enter into } \\
\text { agreements with } \\
\text { custodians. } \\
\text { Written policies } \\
\text { governing data } \\
\text { infrastructure and } \\
\text { associated } \\
\text { security } \\
\text { safeguards must } \\
\text { be in place. A } \\
\text { record of user } \\
\text { activity and } \\
\text { security breaches } \\
\text { must be kept. }\end{array}$ & $\begin{array}{l}\text { Information that is } \\
\text { more than } 120 \text { years } \\
\text { old is not subject to } \\
\text { the Act. Information } \\
\text { on persons that is } \\
\text { accessed more than } \\
50 \text { years after the } \\
\text { person's death is not } \\
\text { subject to the Act. } \\
\text { According to the } \\
\text { Personal Health } \\
\text { Information Act, } \\
\text { researchers and } \\
\text { custodians must } \\
\text { enter into a formal } \\
\text { agreement and } \\
\text { researchers must } \\
\text { adhere to the } \\
\text { conditions set by } \\
\text { research ethics } \\
\text { boards and } \\
\text { custodians. } \\
\text { Additionally, a } \\
\text { written records } \\
\text { retention schedule } \\
\text { must be established } \\
\text { by data purpose and } \\
\text { adhered to. } \\
\text { Information that is } \\
\text { used to update a } \\
\text { health information } \\
\text { record and its user } \\
\text { activity log must be } \\
\text { kept for } 1 \text { year from } \\
\text { the date of the } \\
\text { update. }\end{array}$ & $\begin{array}{l}\text { Disclosure without } \\
\text { consent must be } \\
\text { documented including } \\
\text { what was disclosed and to } \\
\text { whom. } \\
\text { Consent is required for } \\
\text { disclosure to non- } \\
\text { custodians and persons } \\
\text { outside of the Province. } \\
\text { De-identified information } \\
\text { may be stored beyond the } \\
\text { period permitted for the } \\
\text { original data collection } \\
\text { purpose. } \\
\text { According to the Personal } \\
\text { Health Information Act, } \\
\text { researchers and custodians } \\
\text { must enter into a formal } \\
\text { agreement and researchers } \\
\text { must adhere to the } \\
\text { conditions set by research } \\
\text { ethics boards and } \\
\text { custodians. }\end{array}$ & $\begin{array}{l}\text { According to the Personal Health } \\
\text { Information Act, a "record" } \\
\text { means a record of information in } \\
\text { any form or in any medium, } \\
\text { whether in written, } \\
\text { printed, photographic or } \\
\text { electronic form or otherwise, but } \\
\text { does not include a computer } \\
\text { program } \\
\text { or other mechanism that can } \\
\text { produce a record. } \\
\text { Regardless of the format of the } \\
\text { record, the establishment of } \\
\text { safeguards is required. }\end{array}$ & $\begin{array}{l}\text { According to the Personal } \\
\text { Health Information Act, } \\
\text { researchers and custodians } \\
\text { must enter into a formal } \\
\text { agreement and researchers } \\
\text { must adhere to the } \\
\text { conditions set by research } \\
\text { ethics boards and } \\
\text { custodians. } \\
\text { Researchers must disclose } \\
\text { a records retention and } \\
\text { destruction plan and } \\
\text { schedule within the } \\
\text { research plan given to the } \\
\text { custodian. }\end{array}$ \\
\hline $\begin{array}{l}\text { Nunavut } \\
\text { Access to Information and } \\
\text { Protection of Privacy Act } \\
\text { http://www.atipp.gov.nu.ca/ } \\
\text { en/Act.aspx }\end{array}$ & $\begin{array}{l}\text { Public bodies that } \\
\text { collect and maintain } \\
\text { health information. }\end{array}$ & $\begin{array}{l}\text { Public bodies, } \\
\text { researchers who } \\
\text { enter into } \\
\text { agreements with } \\
\text { public bodies }\end{array}$ & $\begin{array}{l}\text { According to the } \\
\text { Access to } \\
\text { Information and } \\
\text { Protection of Privacy } \\
\text { Act, the person to } \\
\text { whom the } \\
\text { information is } \\
\text { disclosed must sign a } \\
\text { formal agreement } \\
\text { and comply with its } \\
\text { conditions. } \\
\text { The removal of } \\
\text { identifiers must be } \\
\text { conducted at the } \\
\text { earliest possible time. }\end{array}$ & $\begin{array}{l}\text { According to the Access to } \\
\text { Information and } \\
\text { Protection of Privacy Act, } \\
\text { the person to whom the } \\
\text { information is } \\
\text { disclosed must sign a } \\
\text { formal agreement and } \\
\text { comply with its conditions. }\end{array}$ & $\begin{array}{l}\text { According to the Access to } \\
\text { Information and Protection of } \\
\text { Privacy Act, "record" means a } \\
\text { record of information in any form } \\
\text { and includes information that is } \\
\text { written, photographed, recorded } \\
\text { or stored in any manner, but does } \\
\text { not include a computer } \\
\text { program or other mechanism that } \\
\text { produces records. } \\
\text { Regardless of the format of the } \\
\text { record, the establishment of } \\
\text { safeguards is required. }\end{array}$ & $\begin{array}{l}\text { The Exceptions to } \\
\text { disclosures do not apply } \\
\text { to information that has } \\
\text { been in a record for more } \\
\text { than } 15 \text { years. } \\
\text { According to the Access } \\
\text { to Information and } \\
\text { Protection of Privacy Act, } \\
\text { the person to whom the } \\
\text { information is } \\
\text { disclosed must sign a } \\
\text { formal agreement and } \\
\text { comply with its } \\
\text { conditions. }\end{array}$ \\
\hline
\end{tabular}

inadvertently personally identify the individual described in the obtained information.

\section{Online Registries}

Special considerations regarding privacy and confidentiality with respect to online registries are addressed in the Online Registries section of this document.

\section{Administration}

Support - In order for a registry to be successful it is necessary to have support on a political, administrative and clinical level. ${ }^{39}$ Collaboration between researchers, policy makers, patient advocates and healthcare providers is important in the design of a sustainable registry. ${ }^{40}$ Support for a registry can be influenced by establishing a steering committee, or expert panel. ${ }^{39}$ Steering committees are important to help insure timelines are met, objectives are clear, and that the interests of the general community are met. ${ }^{39}$ Both ethical and scientific oversight committees can be established to address key issues and make recommendations. ${ }^{41}$ While a steering committee may be functional in terms of operations oversight, many provincial laws require a single data owner (acting as a custodian, trustee, and other equivalent terminology) and therefore it may still be necessary to have a single person who is responsible for the registry data and its custodianship. 
Table 1: Intellectual Property and Ownership Considerations by Province [continued 5]

\begin{tabular}{|c|c|c|c|c|c|c|}
\hline PROVINCE & $\begin{array}{l}\text { Who is responsible } \\
\text { for health } \\
\text { information data }\end{array}$ & $\begin{array}{l}\text { Who can store } \\
\text { health } \\
\text { information } \\
\text { data }\end{array}$ & $\begin{array}{c}\text { How long can } \\
\text { identified health } \\
\text { information be } \\
\text { stored? }\end{array}$ & $\begin{array}{l}\text { Can identified health } \\
\text { information be } \\
\text { transferred to another } \\
\text { location for additional } \\
\text { storage duration }\end{array}$ & $\begin{array}{l}\text { What formats are used to store } \\
\text { health information? }\end{array}$ & $\begin{array}{c}\text { How long must } \\
\text { researchers store data } \\
\text { once a study is closed? }\end{array}$ \\
\hline 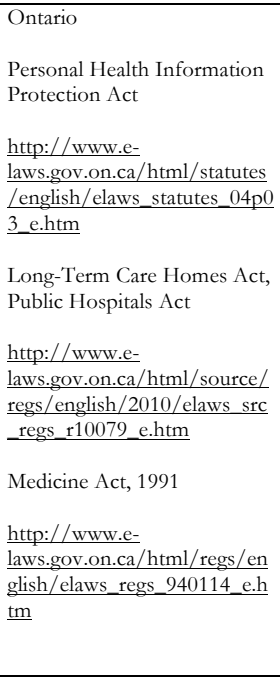 & $\begin{array}{l}\text { Custodians are } \\
\text { responsible for } \\
\text { health data as } \\
\text { defined in the } \\
\text { Personal Health } \\
\text { Information } \\
\text { Protection Act. } \\
\text { Custodians may } \\
\text { include health } \\
\text { professionals or an } \\
\text { individual operating a } \\
\text { group of health } \\
\text { professionals; and } \\
\text { those that operate } \\
\text { home care, long-term } \\
\text { care; communicate } \\
\text { care or hospitals } \\
\text { facilities as defined } \\
\text { by their respective } \\
\text { Acts. }\end{array}$ & $\begin{array}{l}\text { Custodians, } \\
\text { researchers, } \\
\text { information } \\
\text { managers or } \\
\text { other custodian } \\
\text { appointed agents. } \\
\text { Researchers are } \\
\text { permitted to store } \\
\text { and access health } \\
\text { information } \\
\text { provided they } \\
\text { have an ethically } \\
\text { approved } \\
\text { research plan and } \\
\text { have signed an } \\
\text { agreement with } \\
\text { the data } \\
\text { custodian. }\end{array}$ & $\begin{array}{l}\text { There is no retention } \\
\text { period set out in the } \\
\text { Personal Health } \\
\text { Information } \\
\text { Protection Act. The } \\
\text { retention periods are } \\
\text { set out in sector } \\
\text { specific legislation } \\
\text { such as the Long- } \\
\text { Term Care Homes } \\
\text { Act, Public Hospitals } \\
\text { Act and Medicine } \\
\text { Act, 1991. However, } \\
\text { it is a fundamental } \\
\text { fair information } \\
\text { practice that } \\
\text { identifying } \\
\text { information should } \\
\text { not be retained any } \\
\text { longer than is } \\
\text { necessary for the } \\
\text { purpose. } \\
\text { A retention and } \\
\text { disposition schedule } \\
\text { must be outlined in } \\
\text { the research plan. }\end{array}$ & $\begin{array}{l}\text { Records may be kept in a } \\
\text { subject's home or another } \\
\text { location other than the } \\
\text { custodian's premises } \\
\text { provided consent has been } \\
\text { obtained. } \\
\text { Disclosures must be } \\
\text { documented on the health } \\
\text { record and disclosed as } \\
\text { soon as reasonably } \\
\text { possible to the individual } \\
\text { whom the information is } \\
\text { about. } \\
\text { Transfer of records to the } \\
\text { Ontario Archives or other } \\
\text { persons permitted to store } \\
\text { historical records is } \\
\text { permitted. } \\
\text { Identifying information } \\
\text { should not be retained any } \\
\text { longer than is necessary for } \\
\text { the purpose regardless of } \\
\text { the location where it is } \\
\text { being retained or stored. }\end{array}$ & $\begin{array}{l}\text { Records of identifying } \\
\text { information may be stored in } \\
\text { paper or electronic format. } \\
\text { Regardless of format, the } \\
\text { Personal Health } \\
\text { Information Protection Act } \\
\text { requires identifying information } \\
\text { to be retained in a secure manner. } \\
\text { "record" means a record of } \\
\text { information in any form or in any } \\
\text { medium, whether in written, } \\
\text { printed, photographic or } \\
\text { electronic form or otherwise, but } \\
\text { does not include a computer } \\
\text { program or other mechanism that } \\
\text { can produce a record }\end{array}$ & $\begin{array}{l}\text { There is no retention } \\
\text { period set out in the } \\
\text { Personal Health } \\
\text { Information Protection } \\
\text { Act. The research plan } \\
\text { however is required to } \\
\text { specify how long the } \\
\text { information will be } \\
\text { retained in identifying } \\
\text { format. }\end{array}$ \\
\hline $\begin{array}{l}\text { Prince Edward Island } \\
\text { Freedom of Information and } \\
\text { Protection of Privacy Act } \\
\\
\text { http://www.gov.pe.ca/law/st } \\
\text { atutes/pdf/f-15_01.pdf }\end{array}$ & $\begin{array}{l}\text { Public bodies that } \\
\text { collect and maintain } \\
\text { health information. }\end{array}$ & $\begin{array}{l}\text { Public bodies, } \\
\text { researchers who } \\
\text { enter into } \\
\text { agreements with } \\
\text { public bodies }\end{array}$ & $\begin{array}{l}\text { The Freedom of } \\
\text { Information and } \\
\text { Protection of Privacy Act } \\
\text { states that } \\
\text { researchers must sign } \\
\text { a written agreement } \\
\text { to comply with } \\
\text { imposed conditions, } \\
\text { policies and } \\
\text { procedures. } \\
\text { Conditions imposed } \\
\text { by the public body } \\
\text { include conditions } \\
\text { around data security } \\
\text { and confidentiality } \\
\text { and the } \\
\text { removal/destruction } \\
\text { of identifiers at the } \\
\text { earliest possible } \\
\text { opportunity. }\end{array}$ & $\begin{array}{l}\text { The Freedom of Information } \\
\text { and Protection of Privacy Act } \\
\text { states that researchers must } \\
\text { sign a written agreement to } \\
\text { comply with imposed } \\
\text { conditions, policies and } \\
\text { procedures. } \\
\text { Information may be } \\
\text { disclosed to the Public } \\
\text { Records and Archives } \\
\text { Office. Such information } \\
\text { may be available to } \\
\text { researchers if the } \\
\text { information is older than } \\
25 \text { years and disclosure will } \\
\text { not result in an invasion of } \\
\text { privacy; or the individual } \\
\text { has been dead for } 25 \text { years; } \\
\text { or the information is } 75 \text { or } \\
\text { more years old. } \\
\text { Consent for disclosure may } \\
\text { be required. }\end{array}$ & $\begin{array}{l}\text { The Freedom of Information and } \\
\text { Protection of Privacy Act states that a } \\
\text { "record" means a record of } \\
\text { information in any form and } \\
\text { includes notes, images, } \\
\text { audiovisual recordings, x-rays, } \\
\text { books, documents, maps, } \\
\text { drawings, photographs, letters, } \\
\text { vouchers and papers and any } \\
\text { other information that is written, } \\
\text { photographed, recorded or stored } \\
\text { in any manner, but does not } \\
\text { include software or any } \\
\text { mechanism that produces records. } \\
\text { Regardless of the format of the } \\
\text { record, the establishment of } \\
\text { safeguards is required. }\end{array}$ & $\begin{array}{l}\text { The Exceptions to } \\
\text { disclosures do not apply } \\
\text { to information that has } \\
\text { been in a record for more } \\
\text { than } 20 \text { years. } \\
\text { The Freedom of Information } \\
\text { and Protection of Privacy Act } \\
\text { states that researchers } \\
\text { must sign a written } \\
\text { agreement to comply with } \\
\text { imposed conditions, } \\
\text { policies and procedures }\end{array}$ \\
\hline
\end{tabular}

Advisory Council - An external review committee or advisory board can be useful for providing independent oversight and periodic reviews. ${ }^{5}$ Having such a committee may enhance both the feasibility and the credibility of a registry by giving scientific and technical guidance to ensure the smooth operation of the registry, providing recommendations for resolving any issues that may arise during the course of the registry project, and helping to establish the independence of the registry from perceived or actual conflicts of interest. ${ }^{5}$ These committees should include a variety of perspectives (e.g., people who have the disease, caregivers, practitioners, non-governmental organizations, statisticians, lawyers, ethicists, members of the general public, IT experts, knowledge translation specialists, and communication expertise). It is important, however, to keep the size of this council reasonable and to balance conflicting viewpoints regarding the purpose(s) of registries among the different perspectives on the council.

Human Resources - A registry requires consistent human resources. Registries need trained and skilled researchers and clinicians to coordinate, collect and analyze data. ${ }^{39,42}$ A full-time individual should be hired and trained to improve data quality. ${ }^{36}$ In order to maintain long-term interest from collaborators, the Victorian State Trauma Registry aimed to train postdoctoral fellows and newly graduated specialists. ${ }^{39}$

Standard Operating Procedures (SOPS) - are documents that outline the standard methodology applied to a given process. SOPs are an essential best practice in any area desiring high quality, repeatable results. In the case of disease registries, SOPs are particularly important where multiple sites are involved (to ensure all sites follow the same methodology for each task); 
Table 1: Intellectual Property and Ownership Considerations by Province [continued 6]

\begin{tabular}{|c|c|c|c|c|c|c|}
\hline PROVINCE & $\begin{array}{c}\text { Who is responsible } \\
\text { for health } \\
\text { information data }\end{array}$ & $\begin{array}{l}\text { Who can store } \\
\text { health } \\
\text { information } \\
\text { data }\end{array}$ & $\begin{array}{l}\text { How long can } \\
\text { identified health } \\
\text { information be } \\
\text { stored? }\end{array}$ & $\begin{array}{l}\text { Can identified health } \\
\text { information be } \\
\text { transferred to another } \\
\text { location for additional } \\
\text { storage duration }\end{array}$ & $\begin{array}{l}\text { What formats are used to store } \\
\text { health information? }\end{array}$ & $\begin{array}{l}\text { How long must } \\
\text { researchers store data } \\
\text { once a study is closed? }\end{array}$ \\
\hline 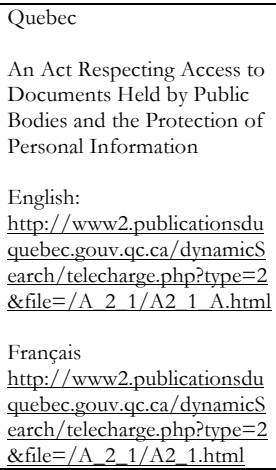 & $\begin{array}{l}\text { Such data are "held" } \\
\text { by Public bodies } \\
\text { (Health and social } \\
\text { services institutions). }\end{array}$ & $\begin{array}{l}\text { Public bodies } \\
\text { (Health and social } \\
\text { services } \\
\text { institutions), } \\
\text { researchers as per } \\
\text { Section } 125 . \\
\text { Personal } \\
\text { information may } \\
\text { not be used for a } \\
\text { purpose other } \\
\text { than for which it } \\
\text { was collected } \\
\text { except where } \\
\text { consent has been } \\
\text { obtained. }\end{array}$ & $\begin{array}{l}\text { Information can be } \\
\text { stored as long as it is } \\
\text { required to fulfill the } \\
\text { intended purpose. } \\
\text { Once the purpose } \\
\text { has been obtained, } \\
\text { the information must } \\
\text { be destroyed in } \\
\text { compliance with the } \\
\text { Archives Act or } \\
\text { Professional Code. } \\
\text { Information } \\
\text { collected for } \\
\text { scientific research is } \\
\text { not subject to these } \\
\text { constraints provided } \\
\text { the information is } \\
\text { never disclosed. }\end{array}$ & $\begin{array}{l}\text { All releases of personal } \\
\text { information must be } \\
\text { documented in a register. }\end{array}$ & $\begin{array}{l}\text { According to An Act Respecting } \\
\text { Access to Documents Held by } \\
\text { Public Bodies and the Protection } \\
\text { of Personal Information, } \\
\text { information can be "recorded in } \\
\text { writing or print, on sound tape or } \\
\text { film, in computerized form, or } \\
\text { otherwise". } \\
\text { Regardless of the format of the } \\
\text { record, the establishment of } \\
\text { safeguards is required. }\end{array}$ & $\begin{array}{l}\text { Information collected for } \\
\text { scientific research } \\
\text { purposes is permitted to } \\
\text { be stored beyond the } \\
\text { restrictions around } \\
\text { purpose placed on other } \\
\text { personal information } \\
\text { repositories, however, } \\
\text { such information may not } \\
\text { be disclosed. }\end{array}$ \\
\hline $\begin{array}{l}\text { Saskatchewan } \\
\text { Health Information } \\
\text { Protection Act (HIPA) } \\
\text { http://www.qp.gov.sk.ca/do } \\
\text { cuments/english/Statutes/St } \\
\text { atutes/H0-021.pdf }\end{array}$ & $\begin{array}{l}\text { Trustees such as } \\
\text { government } \\
\text { institutions; health } \\
\text { authorities; } \\
\text { community clinics; } \\
\text { and licensed health } \\
\text { professionals own } \\
\text { records of personal } \\
\text { information. }\end{array}$ & $\begin{array}{l}\text { A trustee, an } \\
\text { Information } \\
\text { Management } \\
\text { Services Provider } \\
\text { (IMSP), an } \\
\text { employee of a } \\
\text { trustee, an } \\
\text { approved archive } \\
\text { all subject to } \\
\text { compliance with } \\
\text { HIPA, } \\
\text { regulations } \\
\text { particularly } \\
\text { sections 16, 17 } \\
\text { and } 18 . \\
\text { Researchers may } \\
\text { receive data with } \\
\text { subject consent } \\
\text { and ethics } \\
\text { approval. All } \\
\text { researchers } \\
\text { obtaining health } \\
\text { information data } \\
\text { must have an } \\
\text { agreement with } \\
\text { the trustee. A } \\
\text { waiver of consent } \\
\text { is permitted in } \\
\text { certain } \\
\text { circumstances. }\end{array}$ & & $\begin{array}{l}\text { Yes, designated archives } \\
\text { are outlined in the } \\
\text { regulation. These archives } \\
\text { may refuse to accept data } \\
\text { from a trustee. }\end{array}$ & $\begin{array}{l}\text { According to HIPA, a "record" } \\
\text { means a record of information in } \\
\text { any form and includes } \\
\text { information that is written, } \\
\text { photographed, recorded, digitized } \\
\text { or stored in any manner, but does } \\
\text { not include computer programs } \\
\text { or other mechanisms that } \\
\text { produce records. } \\
\text { Regardless of the format of the } \\
\text { record, the establishment of } \\
\text { safeguards is required. }\end{array}$ & $\begin{array}{l}\text { Researchers receiving } \\
\text { health information data } \\
\text { must sign an agreement } \\
\text { with the trustee indicating } \\
\text { when records must be } \\
\text { destroyed. }\end{array}$ \\
\hline $\begin{array}{l}\text { Yukon Territory } \\
\text { Access to Information and } \\
\text { Protection of Privacy Act } \\
\text { http://www.gov.yk.ca/legisla } \\
\text { tion/acts/atipp.pdf }\end{array}$ & $\begin{array}{l}\text { Public bodies that } \\
\text { collect and maintain } \\
\text { health information. } \\
\text { Health information } \\
\text { legislation is pending } \\
\text { in the Yukon } \\
\text { Territory. }\end{array}$ & $\begin{array}{l}\text { Public bodies, } \\
\text { researchers who } \\
\text { enter into } \\
\text { agreements with } \\
\text { public bodies }\end{array}$ & $\begin{array}{l}\text { According to the } \\
\text { Access to } \\
\text { Information and } \\
\text { Protection of Privacy } \\
\text { Act, the person to } \\
\text { whom the } \\
\text { information is } \\
\text { disclosed must sign a } \\
\text { formal agreement } \\
\text { and comply with its } \\
\text { conditions. }\end{array}$ & $\begin{array}{l}\text { According to the Access to } \\
\text { Information and } \\
\text { Protection of Privacy Act, } \\
\text { the person to whom the } \\
\text { information is disclosed } \\
\text { must sign a formal } \\
\text { agreement and comply } \\
\text { with its conditions. }\end{array}$ & $\begin{array}{l}\text { According to the Access to } \\
\text { Information and Protection of } \\
\text { Privacy Act, a "record" includes } \\
\text { books, documents, maps, } \\
\text { drawings, photographs, letters, } \\
\text { vouchers, papers and any other } \\
\text { thing on which information is } \\
\text { recorded or stored by graphic, } \\
\text { electronic, mechanical or other } \\
\text { means, but does not include a } \\
\text { computer program or any other } \\
\text { process or mechanism that } \\
\text { produces records. } \\
\text { Regardless of the format of the } \\
\text { record, the establishment of } \\
\text { safeguards is required. }\end{array}$ & $\begin{array}{l}\text { According to the Access } \\
\text { to Information and } \\
\text { Protection of Privacy Act, } \\
\text { the person to whom the } \\
\text { information is disclosed } \\
\text { must sign a formal } \\
\text { agreement and comply } \\
\text { with its conditions. }\end{array}$ \\
\hline
\end{tabular}


where multiple data collectors are involved (to ensure uniform data collection) and where multiple jurisdictions may necessitate the need to find a process that fits all appropriate regulations/policies. Well written SOPs can help to ensure Good Clinical Practice principles are followed and can help to minimize errors and their associated rework. ${ }^{43}$ A well written SOP uses plain language in a clear and concise format and is best written by someone familiar with the process. ${ }^{43}$ SOPs should have an authorization process and be reviewed and updated on a regular basis. ${ }^{43}$ A useful guideline for constructing SOPs can be found here: http://hub.ucsf.edu/sop-guidelines. ${ }^{44} \mathrm{~A}$ good example of what an SOP manual can look like can be found at http://www.frsq.gouv.qc.ca/en/financement/SOP.shtml. ${ }^{45}$

\section{Intellectual Property}

Data ownership is an important topic to consider with respect to registry design and implementation. Registries involve many people and agencies that could potentially assert claim over ownership of the data. ${ }^{5}$ Specifically, the principal and coinvestigator(s), the involved institutions, funding agencies, and the patients themselves are all, to some degree, stakeholders in the registry. ${ }^{5}$ It is essential to clarify who owns and possesses the registry data a priori. Ownership of health information should be conceptualized with two considerations in mind. The health information contained within the health record is fundamentally owned by the patient, however, the health record itself is owned by the healthcare provider/institution/facility that produced the record. ${ }^{46}$ Under Canadian rights legislation as well as human rights principles and many aspects of provincial legislation, patients fundamentally have a right to access their health information contained within various health records. Registries have a duty to provide this right of access. However, the registry records themselves, like health records are owned by the registry and registry governance documents should clearly stipulate who in the registry operations owns the registry data.

Table 1 addresses intellectual property across relevant national and provincial legislation.

Additionally, as biobanks and registry data are commodities that can be bought and sold, there may be a need to inform participants that it is possible that the biobank with their samples may be sold. ${ }^{7}$ It should be disclosed during the informed consent process and made clear in consent forms that the patient does not have a claim on the discoveries arising from their biological specimens. ${ }^{7}$ Additionally, samples can be used for a variety of purposes and it should be disclosed to participants which ones are being pursued. ${ }^{7}$

\section{Transparency}

It is important to be as transparent as possible about the operation of a registry. ${ }^{5}$ Publicizing such information as the research protocol, data security procedures and other relevant information will help to increase the credibility of the registry. ${ }^{5}$ Producing a website, newsletter and/or articles in various forms of media are also ways to increase registry transparency. ${ }^{5}$

There is a need to be transparent about what may happen at the end of a registry with respect to the data. At a minimum information on how data will be secured or destroyed should be disclosed as well as who will maintain responsibility for the data if they are not destroyed. Additionally, this information must include disclosure of plans with respect to potentially selling data to a third party, especially to a private entity such as a pharmaceutical company.

\section{Foreign Registries}

In addition to having to meet international standards, international registries operating in Canada must meet Canadian standards because in order to operate in a Canadian facility, appropriate institutional research ethics board approval is required. ${ }^{7}$ Ideally a registry should have the capacity to evolve to incorporate data from different nations. Contacting the appropriate international institutions during the registry design stage can help to facilitate the design of a registry that has the potential to be multi-national. ${ }^{7}$

\section{Registry Purpose}

Some activities which may involve the development of a registry may not be subject to ethics review. These activities would fall under the umbrella of quality improvement. They are essential to the improvement of healthcare delivery and are specific and local in nature. ${ }^{47}$ All other activities conducted by registries where generalizable knowledge is produced will fall under the review of research ethics committees in Canada.

\section{Registry Taxonomy}

In "Registries for Evaluating Patient Outcomes: A User's Guide" 5 the Agency for Healthcare Research and Quality (AHRQ) has derived a taxonomy for registries that may be useful in helping to characterize your registry.

Table 2 is an adapted version of this reference.

\section{Policy \& Legislation}

Tables 3 and 4 feature links and information regarding relevant policy and legislation by province. Those considering the design of registries in Canada should review the relevant links for their desired jurisdictions.

\section{RECOMMENDATIONS}

$\checkmark$ All registries operating in Canada (domestic or foreign) should adhere to Canadian ethical, legal and privacy standards and applicable legislation.

$\checkmark$ Registries should pro-actively consider legal and ethical issues within their operating jurisdictions. Careful consideration of issues such as capacity to consent and data confidentiality must be undertaken.

$\checkmark$ Registries should be transparent in their operation. Transparency includes at a minimum clear articulation of the registry purpose; data ownership; data security measures; data usage; and operating term. If a limited operating term is expected, information on how data will be destroyed at the end of the term should be disclosed. It is also recommended that registries make protocols, policies and procedures; and other appropriate documentation available publicly to increase credibility.

$\checkmark$ Registry operation should include an Advisory Council with broad expertise and perspectives. 
$\checkmark$ Participant consent should be considered ongoing and the informed consent process must include adequate time for reflection. Consent may also consist of three components: 1) consent to collection of data; 2) consent to the initial registry research purpose; 3 ) consent to subsequent research uses of the data (i.e. additional research projects). Additionally participants must always have the right to withdraw.

$\checkmark$ Registries including a biobank component must be reviewed by an REB and the purpose of the biobank must be clear and fully disclosed.

$\checkmark$ Registries with plans to sell data to a third party, especially a private entity, must disclose this.

$\checkmark$ The ownership of registry data must be clarified in the initial design and communicated to all stakeholders which may include investigators, researchers, participants, host institutions, and funding agencies.

$\checkmark$ Registry data servers should be housed in a physically secure location inaccessible to the Internet. Ideally, registries will also employ a minimum two-server model where one server stores patient identifiers and the other server stores health information. Anonymization or pseudo-anonymization (coding) should be utilized wherever possible.

$\checkmark$ Registry data access should be controlled by user type and secured through the use of passwords. Electronic backup files should be kept as hard copies present a security risk.

$\checkmark$ Registry data requests should be reviewed using a standardized process and data release procedures should be documented. Subgroups of less than six individuals should be considered identifiable.

$\checkmark$ Registry informed consent forms should include information on the purpose of the registry; how the registry is managed to ensure patient privacy and data security; and why the data being collected is relevant to improving knowledge about the condition and the potential development of treatments.

$\checkmark$ Registries obtaining information regarding someone other than the direct participant (e.g. family member) should avoid collecting this information if it potentially identifies the individual or obtain consent to collect the information. Registries collecting information that may have sensitive implications or required physician reporting must disclose this possibility to participants.

\section{It is recommended that those planning registries:}

$\checkmark$ Address participant concerns about data access and the type of data stored by the registry.

$\checkmark$ Consider graduated levels of consent. ${ }^{48}$

$\checkmark$ Address participant, provider, and stakeholder concerns about data security by establishing a committee to monitor data safety and the release of data rather than having an individual with this responsibility. ${ }^{48}$

$\checkmark$ Encourage recruitment and utilization in a clinical environment, through efficient and effective registry design. An example could be a software platform with clear procedures supporting the registry infrastructure. ${ }^{49}$

$\checkmark$ Consider centralized data collection and curation. ${ }^{50,51}$

$\checkmark$ Select one of two models for patient consent:

a) Written informed consent for the duration of the registry with the option for participant withdrawal and ethical review of research studies utilizing data. ${ }^{12}$

b) Waiver of consent when information is de-identified, not shared, and the option to opt-out is offered..$^{52}$

$\checkmark$ Employ a two-phase review approach to help in obtaining ethics approval for multi-site registries. Phase one involves review of the registry data collection, curation and storage methods as well as operational policies and procedures. This review would focus on confidentiality and privacy. Phase two involves review of specific research projects utilizing registry data. $^{47}$

$\checkmark$ Develop a research network infrastructure that will support the registry and help with policy adherence by providing consistent guidance and technical support. ${ }^{52}$ 
Table 2: Registry Taxonomy by Type

\begin{tabular}{|c|c|c|}
\hline Registry Type & Definition & Examples \\
\hline $\begin{array}{l}\text { Product } \\
\text { Registries }\end{array}$ & $\begin{array}{l}\text { Participants are exposed to a healthcare product such as } \\
\text { a drug or device. Exposure can be brief or can occur } \\
\text { over an extended interval. The registry may feature all } \\
\text { individuals exposed to the product or only a subset of } \\
\text { individuals exposed to the product. }\end{array}$ & $\begin{array}{l}\text { Registry of patients using subcutaneous IVIG pump. } \\
\text { Registry of patients receiving Riluzole. } \\
\text { Pregnancy registry examining safety of epilepsy } \\
\text { medication. }\end{array}$ \\
\hline $\begin{array}{l}\text { Health Services } \\
\text { Registry }\end{array}$ & $\begin{array}{l}\text { Participants are exposed to a particular healthcare } \\
\text { service such as a procedure. These registries may be } \\
\text { used to evaluate the quality of the service provided; or } \\
\text { to monitor patient outcomes. }\end{array}$ & $\begin{array}{l}\text { Registry of patients accessing home care services } \\
\text { following a diagnosis of ALS. } \\
\text { Registry of patients undergoing invasive ventilation } \\
\text { with a neurological condition. }\end{array}$ \\
\hline $\begin{array}{l}\text { Disease or } \\
\text { Condition } \\
\text { Registries }\end{array}$ & $\begin{array}{l}\text { Participants have been diagnosed with a permanent or } \\
\text { temporary medical condition or disease. Enrollment } \\
\text { may be at any time during disease progression or in } \\
\text { some cases may coincide with a particular event. }\end{array}$ & $\begin{array}{l}\text { Registry of patients who have a neuromuscular } \\
\text { disease and have developed cardiomyopathy. } \\
\text { Registry of patients who have suffered a stroke. } \\
\text { Registry of children with atypical seizures. }\end{array}$ \\
\hline
\end{tabular}

Table 3: Summary of Relevant Policy and Legislation [1]

\begin{tabular}{|c|c|c|c|c|}
\hline & Privacy & Research Ethics & Health & Licensing \\
\hline NATIONAL & $\begin{array}{l}\text { Personal Information } \\
\text { Protection and Electronic } \\
\text { Documents Act (PIPEDA) } \\
\text { English: http://laws-lois.justice.gc.ca/PDF/P-8.6.pdf } \\
\text { Français: http://laws-lois.justice.gc.ca/PDF/P-8.6.pdf } \\
\text { Access to Information Act } \\
\text { English: } \mathbf{h t t p : / / l a w s - l o i s . j u s t i c e . g c . c a / e n g / a c t s / A - 1 / ~} \\
\text { Français: http://laws-lois.justice.gc.ca/fra/lois/A-1/ } \\
\text { Privacy Act } \\
\text { English: http://laws-lois.justice.gc.ca/eng/acts/P-21/index.html }\end{array}$ & $\begin{array}{l}\text { TCPS 2-2nd edition of Tri-Council Policy Statement: } \\
\text { Ethical Conduct for Research Involving Humans } \\
\text { English: } \\
\text { http://www.pre.ethics.gc.ca/eng/policy- } \\
\text { politique/initiatives/tcps2-eptc2/Default/ } \\
\text { Français: } \\
\text { http://www.ger.ethique.gc.ca/fra/policy- } \\
\text { politique/initiatives/tcps2-eptc2/Default/ } \\
\text { Canadian Association of Research Ethics Boards: Resources } \\
\text { English: http://www.careb-accer.org/resource } \\
\text { Français: http://www.careb-accer.org/fr/resource }\end{array}$ & & \\
\hline
\end{tabular}

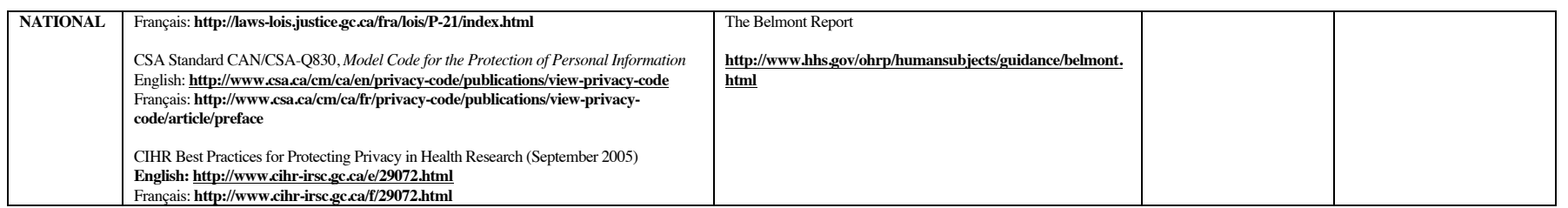

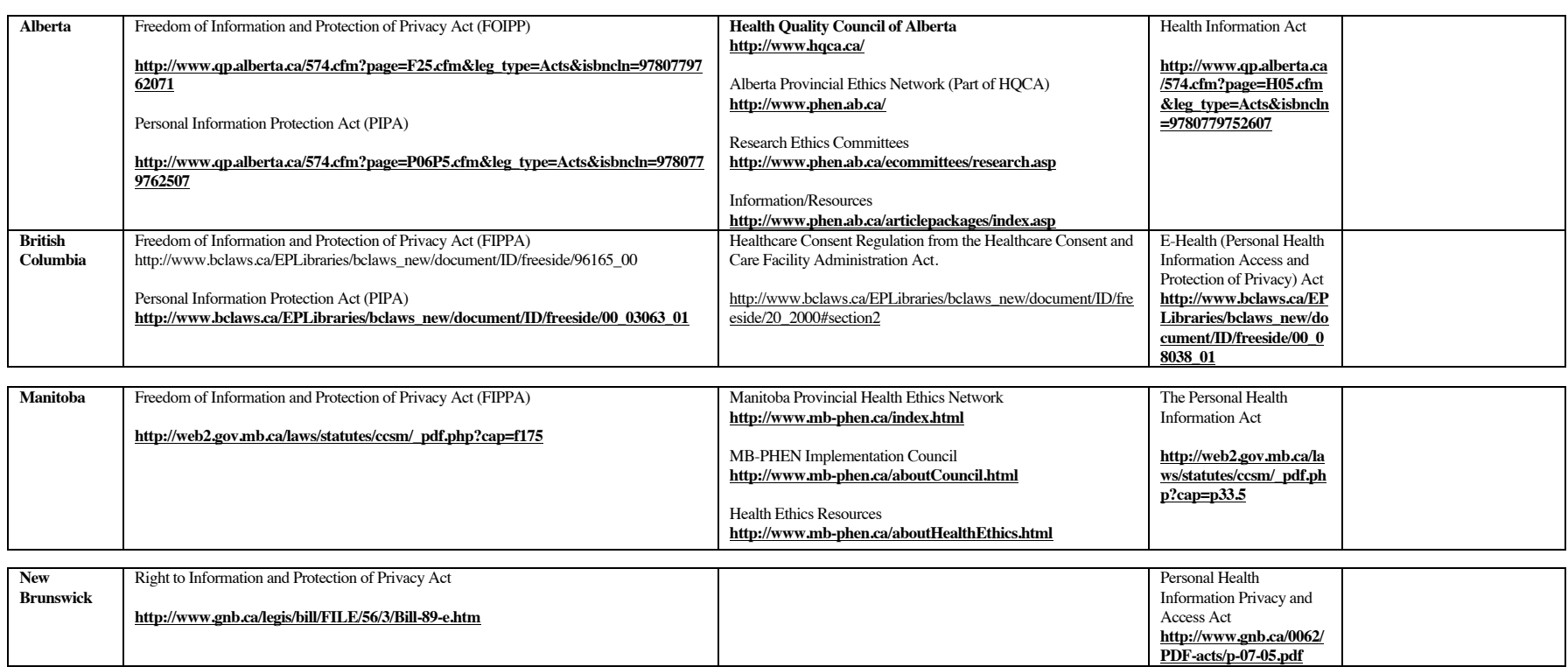

Suppl. 2 - S18 
Table 3: Summary of Relevant Policy and Legislation [continued 2]

\begin{tabular}{|c|c|c|c|c|}
\hline & Privacy & Research Ethics & Health & Licensing \\
\hline $\begin{array}{l}\text { Newfoundland } \\
\text { and } \\
\text { Labrador }\end{array}$ & $\begin{array}{l}\text { Access to Information and Protection of Privacy Act (ATIPPA) } \\
\text { http://assembly.nl.ca/Legislation/sr/statutes/a01-1.htm }\end{array}$ & $\begin{array}{l}\text { Health Research Ethics Authority Act } \\
\text { http://www.assembly.nl.ca/legislation/sr/statutes/h01-2.htm } \\
\text { Health Research Ethics Authority Regulations under the Health } \\
\text { Research Ethics Authority Act } \\
\text { http://www.assembly.nl.ca/legislation/sr/regulations/rc110057 } \\
\underline{\text { htm }} \\
\text { Does your study require ethics review? } \\
\text { http://www.hrea.ca/Ethics-Review-Required.aspx } \\
\text { Health Research Ethics Board http://www.hrea.ca/HREB.aspx }\end{array}$ & $\begin{array}{l}\text { Personal Health } \\
\text { Information Act (PHIA) } \\
\text { http://assembly.nl.ca/Leg } \\
\text { islation/sr/statutes/p07- } \\
\underline{\text { o1.htm }}\end{array}$ & \\
\hline Nova Scotia & $\begin{array}{l}\text { Freedom of Information and Protection of Privacy Act (FOIPOP) } \\
\text { http://nslegislature.ca/legc/statutes/freedom.htm } \\
\text { Privacy Review Officer Act } \\
\text { http://nslegislature.ca/legc/bills/60th_2nd/3rd_read/b234.htm } \\
\text { Personal Information International Disclosure Protection Act (PIIDPA) } \\
\text { http://nslegislature.ca/legc/statutes/persinfo.htm }\end{array}$ & $\begin{array}{l}\text { Nova Scotia Health Ethics Network: } \underline{\text { http://www.nshen.ca/ }} \\
\text { Ethics Resources: } \mathbf{\text { http://www.nshen.ca/ethicsresources.html }} \\
\text { Nova Scotia Health Ethics Network } \\
\text { FAQ/Contact Information } \\
\text { http://www.nshen.ca/fags.html }\end{array}$ & $\begin{array}{l}\text { Personal Health } \\
\text { Information Act } \\
\text { https://www.gov.ns.ca/dh } \\
\text { w/phia/ }\end{array}$ & \\
\hline Ontario & $\begin{array}{l}\text { Freedom of Information and Protection of Privacy Act (FIPPA) } \\
\text { http://www.e-laws.gov.on.ca/html/statutes/english/elaws_statutes_90f31_e.htm } \\
\text { Municipal Freedom of Information and Protection of Privacy Act (MFIPPA) } \\
\text { http://www.e-laws.gov.on.ca/html/statutes/english/elaws_statutes_90m56_e.htm } \\
\text { Manual for the Review of Prescribed Persons and Prescribed Entities } \\
\text { http://www.jpc.on.ca/images/Findings/process.pdf }\end{array}$ & & $\begin{array}{l}\text { The Personal Health } \\
\text { Information Protection Act } \\
\text { (PHIPA) } \\
\text { http://www.e- } \\
\text { laws.gov.on.ca/html/statu } \\
\text { tes/english/elaws_statutes } \\
\text { 04p03_e.htm }\end{array}$ & \\
\hline $\begin{array}{l}\text { Prince } \\
\text { Edward } \\
\text { Island }\end{array}$ & $\begin{array}{l}\text { Freedom of Information and Protection of Privacy Act (FOIPP) } \\
\text { http://www.gov.pe.ca/law/statutes/pdf/f-15 01.pdf }\end{array}$ & $\begin{array}{l}\text { Prince Edward Island Research Ethics Board } \\
\text { http://www.healthpei.ca/reb } \\
\text { Submission Requirements - PEI Research Ethics General } \\
\text { Guidelines } \\
\text { http://www.gov.pe.ca/photos/original/doh_reb_guideli.pdf } \\
\text { Prince Edward Island RESEARCH ETHICS BOARD: Mandate } \\
\text { http://www.gov.pe.ca/photos/original/doh_reb_mandate.pdf }\end{array}$ & $\begin{array}{l}\text { Health PEI: Privacy and } \\
\text { Access } \\
\text { http://www.healthpei.ca/in } \\
\text { dex.php3?number }=102029 \\
\text { \&\&lang=E } \\
\text { No separate legislation. }\end{array}$ & \\
\hline Quebec & $\begin{array}{l}\text { An Act respecting Access to documents held by public bodies and the Protection of } \\
\text { personal informationEnglish: } \\
\text { http://www2.publicationsduquebec.gouv.qc.ca/dynamicSearch/telecharge.php?type=2 } \\
\text { \&file=/A_2_1/A2_1_A.html } \\
\text { Français: } \\
\text { http://www2.publicationsduquebec.gouv.qc.ca/dynamicSearch/telecharge.php?type=2\&file } \\
\text { =/A_2_1/A2_1.html } \\
\text { An Act respecting the protection of personal information in the private sector } \\
\text { English: } \\
\text { http://www2.publicationsduquebec.gouv.qc.ca/dynamicSearch/telecharge.php?type=2 } \\
\text { \&file=/P_39_1/P39_1_A.html } \\
\text { Français: } \\
\text { http//www2.publicationsduquebec.gouv.qc.ca/dynamicSearch/telecharge.php?type=2\&file } \\
\text { =/P_39_1/P39_1.html }\end{array}$ & $\begin{array}{l}\text { Fonds de recherche Santé Québec } \\
\text { English: } \\
\text { http://www.frsq.gouv.qc.ca/en/ethique/ethique.shtml\#02 } \\
\text { Français: http://www.frsq.gouv.qc.ca/fr/ethique/ethique.shtmlı02 } \\
\text { Also refer to: (Governance Framework for Data Banks and } \\
\text { Biobanks used for Health Research (FRSQ, 2006)) } \\
\text { English: } \\
\text { http://www.frsq.gouv.qc.ca/en/ethique/pdfs_ethique/Sommai } \\
\text { re_groupe_conseil_anglais.pdf } \\
\text { Français: } \\
\text { http://www.frsq.gouv.qc.ca/fr/ethique/pdfs_ethique/Rapport } \\
\text { groupe_conseil_francais.pdf } \\
\text { (Code of ethics and professional conduct (FRSQ,2003)) } \\
\text { English: } \\
\text { http://www.frsq.gouv.qc.ca/en/ethique/pdfs_ethique/code_eth } \\
\text { ique_ang.pdf } \\
\text { Français: } \\
\text { http://www.frsq.gouv.qc.ca/fr/ethique/ethique.shtml }\end{array}$ & $\begin{array}{l}\text { Commission d'accès à } \\
\text { l'information du Québec } \\
\text { English: } \\
\text { http://www.cai.gouv.qc.ca/ } \\
\text { english/ } \\
\text { Français: } \\
\text { http://cai.gouv.qc.ca/ }\end{array}$ & \\
\hline Saskatchewan & $\begin{array}{l}\text { Freedom of Information and Protection of Privacy Act (FOIP) } \\
\text { http://www.qp.gov.sk.ca/documents/English/Statutes/Statutes/F22-01.pdf } \\
\text { The Local Authority Freedom of Information and } \\
\text { Protection of Privacy Act (LA FOIP) } \\
\text { http://www.qp.gov.sk.ca/documents/English/Statutes/Statutes/L27-1.pdf } \\
\text { The Privacy Act } \\
\text { http://www.qp.gov.sk.ca/documents/English/Statutes/Statutes/P24.pdf } \\
\text { OIPC Investigation Report 2005-002: http://www.oipc.sk.ca/Reports/H-2005-002.pdf }\end{array}$ & $\begin{array}{l}\text { HIPA Approved Ethics Committees } \\
\text { http://www.health.gov sk.ca/approved-research-ethics- } \\
\text { committee }\end{array}$ & $\begin{array}{l}\text { Health Information } \\
\text { Protection Act (HIPA) } \\
\text { http://www.qp.govsk.ca/ } \\
\text { documents//english/Statut } \\
\text { es/Statutes/H0-021.pdf } \\
\text { HIPA Checklist } \\
\text { http://www.health.gov.sk. } \\
\text { ca/hipa-checklist }\end{array}$ & \\
\hline $\begin{array}{l}\text { Northwest } \\
\text { Territories }\end{array}$ & $\begin{array}{l}\text { Access to Information and Protection of Privacy Act } \\
\text { http://www.justice.gov.nt.ca/pdf/ACTS/Access\% 20to\% 20Information\%20and\%20P } \\
\text { rotection\%20of\% 20Privacy.pdf }\end{array}$ & & & $\begin{array}{l}\text { Northwest Territories Licensing } \\
\text { http://www.nwtresearch.com/lic } \\
\text { ensing } \\
\text { (Scientists Act } \\
\text { http://www.nwtresearch.com/lic } \\
\text { ensing/nwt-scientists-act) } \\
\end{array}$ \\
\hline Nunavut & $\begin{array}{l}\text { Access to Information and Protection of Privacy Act (ATIPP) } \\
\text { http://www.atipp.gov.nu.ca/en/Act.aspx }\end{array}$ & & & $\begin{array}{l}\text { Nunavut Research Institute: } \\
\text { Licensing Process } \\
\text { http://www.nri.nu.ca/apps/auth } \\
\underline{\text { oring/dspPage.aspx?page=proc }} \\
\underline{\text { ess }}\end{array}$ \\
\hline Yukon & $\begin{array}{l}\text { Access to Information and Protection of Privacy Act } \\
\text { http://www.gov.yk.ca/legislation/acts/atipp.pdf }\end{array}$ & & & $\begin{array}{l}\text { Guidebook on Scientific Research } \\
\text { in the Yukon } \\
\text { http://www.tc.gov.yk.ca/pdf/scie } \\
\text { nce_research_guidelines.pdf } \\
\text { Scientists and Explorers Act } \\
\text { http://www.tc.gov.yk.ca/pdf/scie } \\
\text { ntists_and_explorers_act.pdf } \\
\text { Scientists and Explorers License } \\
\text { http://www.tc.gov.yk.ca/scientist } \\
\text { s_explorers.html }\end{array}$ \\
\hline
\end{tabular}


Table 4: Registry Requirements \& Considerations by Province [1]

\begin{tabular}{|c|c|c|c|c|c|}
\hline $\begin{array}{l}\text { Province or Territory } \\
\text { (Corresponding Legislation) }\end{array}$ & $\begin{array}{l}\text { Is a Privacy Impact Assessment } \\
\text { required? (yes/no) }\end{array}$ & $\begin{array}{l}\text { Is Research Ethics Board Approval } \\
\text { required? (yes/no) }\end{array}$ & $\begin{array}{l}\text { Permission from the } \\
\text { health authority or } \\
\text { other health } \\
\text { administration body }\end{array}$ & Patient Consent & Data Matching or Data Linkage \\
\hline $\begin{array}{l}\text { Alberta } \\
\text { (Health Information Act) } \\
\text { http://www.qp.alberta.ca/574.cfm? } \\
\text { page=H05.cfm\&leg_type=Acts\&is } \\
\text { bncln=9780779752607 }\end{array}$ & $\begin{array}{l}\text { Yes. This is to be completed by } \\
\text { custodians in accordance with } \\
64(1) \text { of the Health Information } \\
\text { Act. } \\
\text { According to sections } 70(2) \text { and } \\
71(2) \text { of the Health Information } \\
\text { Act, privacy impact assessments } \\
\text { are required for data matching. } \\
\text { Consult } \\
\text { http://www.oipc.ab.ca/Content_ } \\
\text { Files/Files/PIAs/PIA_Requireme } \\
\text { nts_2010.pdf for more } \\
\text { information }\end{array}$ & $\begin{array}{l}\text { Yes according to 27(1), } 49 \text { and } 50 \text { of } \\
\text { the Health Information Act } \\
\text { According to the Health Information } \\
\text { Act ,(v) "research" means academic, } \\
\text { applied or scientific research that } \\
\text { necessitates the use of individually } \\
\text { identifying health information }\end{array}$ & $\begin{array}{l}\text { Permission from } \\
\text { custodian needed } \\
\text { according to sections } \\
51-56 \text { of the Health } \\
\text { Information Act }\end{array}$ & $\begin{array}{l}\text { Not required for non-identifying } \\
\text { information according to section } 32 \text { of } \\
\text { the Health Information Act. } \\
\text { Required for individually identifying } \\
\text { information according to section } 34 \\
\text { and subject to sections } 35-40 \text { of the } \\
\text { Health Information Act. } \\
\text { Requirement of consent for disclosure } \\
\text { of health information for research to } \\
\text { be determined by ethics committee } \\
\text { according to } 50 \text { (1)(a) of the Health } \\
\text { Information Act }\end{array}$ & $\begin{array}{l}\text { According to the Health Information Act, } \\
\text { (g) "data matching" means the creation of } \\
\text { individually identifying health information } \\
\text { by combining individually identifying or } \\
\text { non-identifying health information or } \\
\text { other information from } 2 \text { or more } \\
\text { electronic databases, without the consent } \\
\text { of the individuals who are the subjects of } \\
\text { the information. } \\
\text { To be conducted in accordance with } \\
\text { sections 70-72. Data matching for research } \\
\text { (Section 72) must be done in accordance } \\
\text { with sections } 48-56 \text { of the Health } \\
\text { Information Act (disclosure for research } \\
\text { purposes). }\end{array}$ \\
\hline 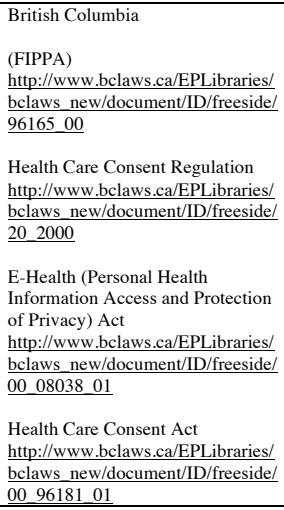 & $\begin{array}{l}\text { Yes. In order to be compliant } \\
\text { with FIPPA, a PIA is required for } \\
\text { all initiatives that deal with } \\
\text { personal information. } \\
\text { Consult } \\
\text { http://www.cio.gov.bc.ca/cio/pri } \\
\text { v_leg/foippa/pia/pia_index.page } \\
\text { and } \\
\text { http://www.oipc.bc.ca/index.php } \\
\text { ?option=com_content\&view=art } \\
\text { icle\&id=80\%3Apublic-sector-g- } \\
\text { privacy-impact-assessment- } \\
\text { pia\&catid=16\%3Aresources- } \\
\text { for-public-bodies\&Itemid=1 for } \\
\text { more information }\end{array}$ & $\begin{array}{l}\text { Yes and boards with authority are } \\
\text { defined in the Health Care Consent } \\
\text { Regulation. }\end{array}$ & $\begin{array}{l}\text { Permission needed } \\
\text { from data stewardship } \\
\text { committee in } \\
\text { accordance with } \\
\text { section } 14 \text { of the E- } \\
\text { Health (Personal } \\
\text { Health Information } \\
\text { Access and Protection } \\
\text { of Privacy) Act }\end{array}$ & $\begin{array}{l}\text { Patient consent is always required } \\
\text { when information is being disclosed } \\
\text { outside of Canada in accordance with } \\
\text { section } 14(2 \mathrm{~b} \text { ) of the E-Health } \\
\text { (Personal Health Information Access } \\
\text { and Protection of Privacy) Act } \\
\text { Consent is also always required where } \\
\text { treatment or intervention will be } \\
\text { provided (Health Care Consent Act). } \\
\text { Otherwise not specified in legislation } \\
\text { but may be a condition of disclosure } \\
\text { set by data stewardship committee } \\
\text { according to section 14(3) of the E- } \\
\text { Health (Personal Health Information } \\
\text { Access and Protection of Privacy) Act }\end{array}$ & $\begin{array}{l}\text { According to section } 3(5) \text { of the E-Health } \\
\text { (Personal Health Information Access and } \\
\text { Protection of Privacy) Act: If a health } \\
\text { information bank is established or } \\
\text { designated by a designation order, } \\
\text { personal health information may be } \\
\text { collected, used and, subject to sections } 14 \\
\text { [disclosure for planning or research } \\
\text { purposes] and } 19 \text { [information-sharing } \\
\text { agreements required for disclosure], } \\
\text { disclosed through the health information } \\
\text { bank by a person who is authorized to do } \\
\text { so by the designation order, according to } \\
\text { the terms of the designation order. }\end{array}$ \\
\hline $\begin{array}{l}\text { Manitoba } \\
\text { FIPPA } \\
\text { http://web2.gov.mb.ca/laws/statutes } \\
\text { /ccsm/_pdf.php?cap=f175 } \\
\text { The Personal Health Information } \\
\text { Act } \\
\text { http://web2.gov.mb.ca/laws/statutes } \\
\text { lccsm/_pdf.php?cap=p33.5 }\end{array}$ & $\begin{array}{l}\text { No reference to this found in } \\
\text { legislation } \\
\text { Consult } \\
\text { http://www.gov.mb.ca/chc/fippa } \\
\text { public_bodies/privacy_impact__ } \\
\text { assessment.html for more } \\
\text { information }\end{array}$ & $\begin{array}{l}\text { In Manitoba, the legislation refers to } \\
\text { REBs as "Institutional Research } \\
\text { Review Committees" } \\
\text { Approval from institutional research } \\
\text { review committees is necessary } \\
\text { according to section } 24 \text { of the The } \\
\text { Personal Health Information Act. }\end{array}$ & $\begin{array}{l}\text { Approval may be } \\
\text { given by those } \\
\text { specified in section } \\
24(2) \text { in accordance } \\
\text { with section } 24 \text { of the } \\
\text { The Personal Health } \\
\text { Information Act. }\end{array}$ & $\begin{array}{l}\text { Sometimes required (sections } 21 \text { and } \\
\text { 22). However, sometimes not be } \\
\text { required according to section } 24(3) \text { of } \\
\text { the The Personal Health Information } \\
\text { Act. } \\
\text { When consent is required, follow it } \\
\text { must be collected/retained according } \\
\text { to Section } 19 \text { of the The Personal } \\
\text { Health Information Act. }\end{array}$ & $\begin{array}{l}\text { According to Section } 28(\mathrm{e}) \text { of the The } \\
\text { Personal Health Information Act, the } \\
\text { Ombudsman may comment of the } \\
\text { implication of disclosing personal health } \\
\text { information for linkage and using } \\
\text { technology to collect, store and transfer } \\
\text { personal health information. }\end{array}$ \\
\hline $\begin{array}{l}\text { New Brunswick } \\
\text { (Personal Health Information } \\
\text { Privacy Access Act.) } \\
\text { http://www.gnb.ca/0062/PDF- } \\
\text { acts/p-07-05.pdf }\end{array}$ & $\begin{array}{l}\text { Yes, according to section } 56 \text { of } \\
\text { the Personal Health Information } \\
\text { Privacy Access Act. } \\
\text { With respect to data matching, a } \\
\text { privacy impact assessment is } \\
\text { required when one custodian uses } \\
\text { data held by another custodian } \\
\text { (section 56) but not when using } \\
\text { data in its own custody for } \\
\text { authorized purposes (Section 57) }\end{array}$ & $\begin{array}{l}\text { According to } 43(2) \text { of the Personal } \\
\text { Health Information Privacy Access } \\
\text { Act "An approval may be given by a } \\
\text { research review body that meets the } \\
\text { requirements prescribed by } \\
\text { regulation." } \\
\text { "research" means a systematic } \\
\text { investigation designed } \\
\text { to develop or establish principles, } \\
\text { facts or general knowledge, or any } \\
\text { combination of them, and includes the } \\
\text { development, testing and evaluation } \\
\text { of research. }\end{array}$ & $\begin{array}{l}\text { Approval from } \\
\text { custodian needed in } \\
\text { accordance with } \\
\text { section (43) of the } \\
\text { Personal Health } \\
\text { Information Privacy } \\
\text { Access Act. }\end{array}$ & $\begin{array}{l}\text { Consent is required unless obtaining } \\
\text { consent is deemed by a research } \\
\text { review body to be unreasonable or } \\
\text { impractical (according to section } \\
\text { 43(3) of the Personal Health } \\
\text { Information Privacy Access Act) }\end{array}$ & $\begin{array}{l}\text { According to section } 37(6)(\mathrm{d}) \text { of the } \\
\text { Personal Health Information Privacy } \\
\text { Access Act, a custodian shall disclose } \\
\text { personal health information without } \\
\text { individual consent to a custodian who } \\
\text { compiles or maintains a registry for } \\
\text { facilitating or improving health care or } \\
\text { that involves the storage or donation of } \\
\text { body parts and substances. } \\
\text { "data matching" means the creation of } \\
\text { identifying information by combining } \\
\text { identifying information or deidentified } \\
\text { personal health information or other } \\
\text { information from } 2 \text { or more electronic data } \\
\text { bases or } 2 \text { or more electronic records. } \\
\text { Must be done in accordance with section } \\
57 \text { of the Personal Health Information } \\
\text { Privacy Access Act. }\end{array}$ \\
\hline $\begin{array}{l}\text { Newfoundland and Labrador } \\
\text { Personal Health Information Act } \\
\text { (PHIA) } \\
\text { http://assembly.nl.ca/Legislation/sr/ } \\
\text { statutes/p07-01.htm } \\
\text { Health Research Ethics Authority } \\
\text { Act } \\
\text { http://www.assembly.nl.ca/legislati } \\
\text { on/sr/statutes/h01-2.htm }\end{array}$ & $\begin{array}{l}\text { Privacy Impact Assessments are } \\
\text { done as a self-monitoring tool to } \\
\text { ensure compliance with the } \\
\text { Personal Health Information Act. } \\
\text { A toolkit including PIA forms is } \\
\text { available at: } \\
\text { http://www.health.gov.nl.ca/healt } \\
\underline{\mathrm{h} / \mathrm{PHIA} /}\end{array}$ & $\begin{array}{l}\text { Yes according to section } 44 \text { of PHIA } \\
\text { as well as the Health Research Ethics } \\
\text { Authority Act } \\
\text { According to PHIA, "research" means } \\
\text { a systematic investigation designed to } \\
\text { develop or establish principles or facts } \\
\text { or to generate knowledge, or any } \\
\text { combination of principles, facts and } \\
\text { knowledge, and includes the } \\
\text { development, testing and evaluation } \\
\text { of research. }\end{array}$ & $\begin{array}{l}\text { Approval from } \\
\text { custodian is needed in } \\
\text { accordance with } \\
\text { section } 44 \text { and the } \\
\text { Health Research } \\
\text { Ethics Authority Act. } \\
\text { Custodians must also } \\
\text { adhere to sections } 48 \\
\text { and } 49 \text { when } \\
\text { disclosing information. }\end{array}$ & $\begin{array}{l}\text { Consent is required according to } \\
\text { section } 36 \text {. However, according to } \\
\text { section } 44 \text {, disclosure without consent } \\
\text { is permitted in accordance with Health } \\
\text { Research Ethics Authority Act. }\end{array}$ & $\begin{array}{l}\text { According to section 39(4)(d), a custodian } \\
\text { shall disclose personal health information } \\
\text { without individual consent to a custodian } \\
\text { who compiles or maintains a registry for } \\
\text { facilitating or improving health care or } \\
\text { that involves the storage or donation of } \\
\text { body parts and function. } \\
\text { According to Section } 79(\mathrm{e}) \text {, the } \\
\text { Commissioner may comment of the } \\
\text { implications of using and disclosing } \\
\text { personal health information for linkage } \\
\text { and using technology to collect, store and } \\
\text { transfer personal health information. }\end{array}$ \\
\hline
\end{tabular}


Table 4: Registry Requirements \& Considerations by Province [continued 2]

\begin{tabular}{|c|c|c|c|c|c|}
\hline $\begin{array}{l}\text { Province or Territory } \\
\text { (Corresponding Legislation) }\end{array}$ & $\begin{array}{l}\text { Is a Privacy Impact Assessment } \\
\text { required? (yes/no) }\end{array}$ & $\begin{array}{l}\text { Is Research Ethics Board Approval } \\
\text { required? (yes/no) }\end{array}$ & \begin{tabular}{|l|}
$\begin{array}{l}\text { Permission from the } \\
\text { health authority or } \\
\text { other health } \\
\text { administration body }\end{array}$ \\
\end{tabular} & Patient Consent & Data Matching or Data Linkage \\
\hline $\begin{array}{l}\text { Nova Scotia } \\
\text { (Personal Health Information Act) } \\
\text { https://www.gov.ns.ca/dhw/phia/ }\end{array}$ & $\begin{array}{l}\text { Yes may be required by some } \\
\text { institutions. Not required in } \\
\text { legislation. } \\
\text { Consult the following for more } \\
\text { information: } \\
\text { http://www.gov.ns.ca/just/IAP/_ } \\
\text { \%ocs/Appendix\% 20B\%20PIA } \\
\text { 20Template.pdf }\end{array}$ & $\begin{array}{l}\text { Yes, according to sections } 55 \text { and } 57 \\
\text { of the Personal Health Information } \\
\text { Act. Note that a research plan must be } \\
\text { submitted in accordance with section } \\
59 \text { of the Personal Health Information } \\
\text { Act. } \\
\text { Note that according to section } 53 \text { of } \\
\text { the Personal Health Information Act } \\
\text { planning and management of the } \\
\text { health system does not constitute } \\
\text { research. }\end{array}$ & $\begin{array}{l}\text { Approval from } \\
\text { custodian needed in } \\
\text { accordance with } \\
\text { sections } 54 \text { and } 56-60 \\
\text { of the Personal Health } \\
\text { Information Act }\end{array}$ & $\begin{array}{l}\text { Sometimes Required. According to } \\
\text { section } 57 \text { of the Personal Health } \\
\text { Information Act the research ethics } \\
\text { board and custodian determine } \\
\text { whether consent is required. } \\
\text { When consent is required, sections } \\
13-23 \text { of the Personal Health } \\
\text { Information Act must be followed. }\end{array}$ & $\begin{array}{l}\text { According to the Personal Health } \\
\text { Information Act, (a) "data matching" } \\
\text { means the creation of individual } \\
\text { identifying health information by } \\
\text { combining individual identifying or non- } \\
\text { identifying health information or other } \\
\text { information from } \\
\text { two or more databases without the consent } \\
\text { of the individuals who are the subjects of } \\
\text { the information } \\
\text { According to sections } 59(3)(\mathrm{e}) \text { and } \\
59(3)(\mathrm{j}) \text { of the Personal Health } \\
\text { Information Act, a research plan must } \\
\text { explain how linkage of personal health } \\
\text { information to other information will be } \\
\text { conducted and why data matching is } \\
\text { required. Data matching must be done in } \\
\text { accordance with sections } 53-60 \text { of the } \\
\text { Personal Health Information Act. }\end{array}$ \\
\hline $\begin{array}{l}\text { Ontario } \\
\text { (Personal Health Information } \\
\text { Protection Act) } \\
\text { http://www.e-- } \\
\text { laws.gov.on.ca/html/statutes/englis } \\
\text { h/elaws_statutes_04p03_e.htm }\end{array}$ & $\begin{array}{l}\text { Not required under legislation but } \\
\text { viewed as a best practice by most } \\
\text { health organizations. } \\
\text { Consult the following for more } \\
\text { information: } \\
\text { http://www.ipc.on.ca/images/Re } \\
\text { sources/up-phipa_pia_e.pdf }\end{array}$ & $\begin{array}{l}\text { Yes, according to section 44(3) and } \\
44(4) \text { of the Personal Health } \\
\text { Information Protection Act } \\
\text { According to the Personal Health } \\
\text { Information Protection Act "research" } \\
\text { means a systematic investigation } \\
\text { designed to develop or establish } \\
\text { principles, facts or generalizable } \\
\text { knowledge, or any combination of } \\
\text { them, and includes the development, } \\
\text { testing and evaluation of research }\end{array}$ & $\begin{array}{l}\text { Approval from } \\
\text { custodian needed in } \\
\text { accordance with } \\
\text { section } 44 \text { of the } \\
\text { Personal Health } \\
\text { Information Protection } \\
\text { Act. } \\
\text { Note section } 30 \text { of the } \\
\text { Personal Health } \\
\text { Information Protection } \\
\text { Act. }\end{array}$ & $\begin{array}{l}\text { Consent required according to section } \\
29 \text { of the Personal Health Information } \\
\text { Protection Act and must be in } \\
\text { accordance with sections } 18-28 \text { of the } \\
\text { Personal Health Information } \\
\text { Protection Act. } \\
\text { However, a research ethics board may } \\
\text { need that it is impractical to obtain } \\
\text { consent according to section } 44(3)(d) \\
\text { of the Personal Health Information } \\
\text { Protection Act }\end{array}$ & $\begin{array}{l}\text { According to section } 39(1)(\mathrm{c}) \text { of the } \\
\text { Personal Health Information Protection } \\
\text { Act, a custodian may disclose personal } \\
\text { health information to a prescribed person } \\
\text { who compiles or maintains a registry for } \\
\text { facilitating or improving health care or } \\
\text { that involves the storage or donation of } \\
\text { body parts and substances. }\end{array}$ \\
\hline $\begin{array}{l}\text { Prince Edward Island } \\
\text { (Freedom of Information and } \\
\text { Protection of Privacy Act) } \\
\text { http://www.gov.pe.ca/law/statutes/ } \\
\text { pdf/f-15_01.pdf }\end{array}$ & $\begin{array}{l}\text { No legislative requirement } \\
\text { Some institutions may require } \\
\text { this internally. } \\
\text { http://www.gov.pe.ca/photos/ori } \\
\text { ginal/oipc_pia.pdf }\end{array}$ & $\begin{array}{l}\text { No reference to this found in } \\
\text { legislation. There is reference in the } \\
\text { Pharmaceutical Information Act } \\
\text { which names only the Prince Edward } \\
\text { Island Research Ethics Board and the } \\
\text { University of Prince Edward Island } \\
\text { Research Ethics Board. A Health } \\
\text { Research Ethics Board was formed } \\
\text { but is currently without an arm's } \\
\text { length sponsor (Feb 2012). }\end{array}$ & $\begin{array}{l}\text { Approval from public } \\
\text { body needed in } \\
\text { accordance with } \\
\text { section } 39 \text { and } 40 \text { of } \\
\text { the Freedom of } \\
\text { Information and } \\
\text { Protection of Privacy } \\
\text { Act. }\end{array}$ & $\begin{array}{l}\text { According to section 15(4)(a) of the } \\
\text { Freedom of Information and } \\
\text { Protection of Privacy Act, disclosure } \\
\text { of medical, psychiatric or } \\
\text { psychological history, diagnosis, } \\
\text { condition, treatment or evaluation is } \\
\text { an unreasonable invasion of a third } \\
\text { party's personal privacy. } \\
\text { However, according to section } \\
15(2)(a) \text { of the Freedom of } \\
\text { Information and Protection of Privacy } \\
\text { Act, disclosure of such information is } \\
\text { not an invasion of a third party's } \\
\text { personal privacy if the third party has } \\
\text { given written consent. }\end{array}$ & $\begin{array}{l}\text { According to section 39(b) of the Freedom } \\
\text { of Information and Protection of Privacy } \\
\text { Act, a public body may disclose } \\
\text { information for research if the record } \\
\text { linkage is not harmful and benefits are in } \\
\text { public interest. } \\
\text { According to Section }(50)(1)(\mathrm{e}) \text { of the } \\
\text { Freedom of Information and Protection of } \\
\text { Privacy Act, the Commissioner may } \\
\text { comment of the implications of using and } \\
\text { disclosing personal information for record } \\
\text { linkage } \\
\text { According to section (77(1)(k) of the } \\
\text { Freedom of Information and Protection of } \\
\text { Privacy Act, the Lieutenant Governor in } \\
\text { Council may make regulations regarding } \\
\text { standards and procedures for data sharing, } \\
\text { data matching and data linkage. }\end{array}$ \\
\hline $\begin{array}{l}\text { Quebec } \\
\text { (An Act respecting Access to } \\
\text { documents held by public bodies } \\
\text { and the Protection of personal } \\
\text { information) } \\
\text { English: } \\
\text { http://www2.publicationsduquebec. } \\
\text { gouv.qc.ca/dynamicSearch/telechar } \\
\text { ge.php?type=2\&file=/A_2_1/A2_1 } \\
\text { A.html } \\
\text { Français } \\
\text { http://www2.publicationsduquebec. } \\
\text { gouv.qc.ca/dynamicSearch/telechar } \\
\text { ge.php?type=2\&file=/A_2_1/A2_1. } \\
\text { html } \\
\text { Commission d'accès à } \\
\text { l'information du Québec } \\
\text { English: } \\
\text { http://www.cai.gouv.qc.ca/english/ } \\
\text { Français } \\
\text { http://cai.gouv.qc.ca/ } \\
\text { FRSQ } \\
\text { English: } \\
\text { http://www.frsq.gouv.qc.ca/en/ethi } \\
\text { que/ethique.shtml } \\
\text { Français } \\
\text { http://www.frsq.gouv.qc.ca//fr/ethiq } \\
\text { ue/ethique.shtml }\end{array}$ & $\begin{array}{l}\text { No reference to this found in } \\
\text { legislation }\end{array}$ & $\begin{array}{l}\text { By ministerial decree the FRSQ } \\
\text { (Fonds de recherche Santé) is charged } \\
\text { with administering policy and } \\
\text { procedure around research ethics. }\end{array}$ & $\begin{array}{l}\text { Approval needed by } \\
\text { the Commission in } \\
\text { accordance with } \\
\text { section } 125 \text { of An Act } \\
\text { respecting Access to } \\
\text { documents held by } \\
\text { public bodies and the } \\
\text { Protection of personal } \\
\text { information. }\end{array}$ & $\begin{array}{l}\text { Not required if approved by the } \\
\text { Commission in accordance with } \\
\text { section } 125 \text { of An Act respecting } \\
\text { Access to documents held by public } \\
\text { bodies and the Protection of personal } \\
\text { information. }\end{array}$ & $\begin{array}{l}\text { May require an application to the } \\
\text { Commission d'accès à l'information du } \\
\text { Québec }\end{array}$ \\
\hline
\end{tabular}


Table 4: Registry Requirements \& Considerations by Province [continued 3]

\begin{tabular}{|c|c|c|c|c|c|}
\hline $\begin{array}{l}\text { Province or Territory } \\
\text { (Corresponding Legislation) }\end{array}$ & $\begin{array}{l}\text { Is a Privacy Impact Assessment } \\
\text { required? (yes/no) }\end{array}$ & $\begin{array}{l}\text { Is Research Ethics Board Approval } \\
\text { required? (yes/no) }\end{array}$ & $\begin{array}{l}\text { Permission from the } \\
\text { health authority or } \\
\text { other health } \\
\text { administration body } \\
\end{array}$ & Patient Consent & Data Matching or Data Linkage \\
\hline $\begin{array}{l}\text { Saskatchewan } \\
\text { (Health Information Protection } \\
\text { Act) } \\
\text { http://www.qp.gov.sk.ca/document } \\
\text { s/english/Statutes/Statutes/H0- } \\
\text { 021.pdf }\end{array}$ & $\begin{array}{l}\text { No legislative requirement, } \\
\text { however, considered a best } \\
\text { practice. } \\
\text { Consult the following for more } \\
\text { information: } \\
\text { http://www.oipc.sk.ca/resources } \\
\underline{\text { htm }} \\
\text { http://www.oipc.sk.ca/Resource } \\
\text { s/PIA_HIPA.pdf }\end{array}$ & $\begin{array}{l}\text { Yes according to section } 29 \text { of the } \\
\text { Health Information Protection Act } \\
\text { (HIPA). }\end{array}$ & $\begin{array}{l}\text { Approval from trustee } \\
\text { or designated archive } \\
\text { needed in accordance } \\
\text { with section } 29 \text { of the } \\
\text { Health Information } \\
\text { Protection Act } \\
\text { (HIPA). }\end{array}$ & $\begin{array}{l}\text { According to section 29(2) of the } \\
\text { Health Information Protection Act } \\
\text { (HIPA), consent is not required if it is } \\
\text { deemed to be "not reasonably } \\
\text { practical" for consent to be obtained. }\end{array}$ & $\begin{array}{l}\text { Will require an agreement between the } \\
\text { researcher and data trustee. May require } \\
\text { an application to Ministry of Health } \\
\text { (public admin data). }\end{array}$ \\
\hline $\begin{array}{l}\text { Northwest Territories } \\
\text { (Access to Information and } \\
\text { Protection of Privacy Act and the } \\
\text { Scientists Act) } \\
\text { http://www.justice.gov.nt.ca/pdf/A } \\
\text { CTS/Access } \% 20 \text { to } \% 20 \text { Information } \\
\% 20 \text { and } \% 20 \text { Protection } \% 20 \text { of } \% 20 \mathrm{P} \\
\text { rivacy.pdf } \\
\text { Scientists Act } \\
\text { http://www.nwtresearch.com/licens } \\
\text { ing/nwt-scientists-act }\end{array}$ & $\begin{array}{l}\text { No legislative requirement. No } \\
\text { privacy office requirement. }\end{array}$ & $\begin{array}{l}\text { According to the Scientists Act, those } \\
\text { who want to conduct research or } \\
\text { collect specimens must hold a license } \\
\text { issued under the act. These licenses } \\
\text { are issued by the Commissioner }\end{array}$ & $\begin{array}{l}\text { Approval from public } \\
\text { body needed in } \\
\text { accordance with } \\
\text { section } 49 \text { of the } \\
\text { Access to Information } \\
\text { and Protection of } \\
\text { Privacy Act }\end{array}$ & $\begin{array}{l}\text { Yes, according to sections } 4(\mathrm{a}), \\
(24)(2)(a), 43,48 \text { of the Access to } \\
\text { Information and Protection of Privacy } \\
\text { Act }\end{array}$ & $\begin{array}{l}\text { Section 49(b) of the Access to Information } \\
\text { and Protection of Privacy Act, a public } \\
\text { body may disclose information for } \\
\text { research if the record linkage is not } \\
\text { harmful and benefits are in public interest }\end{array}$ \\
\hline $\begin{array}{l}\text { Nunavut } \\
\text { (Access to Information and } \\
\text { Protection of Privacy Act) } \\
\text { http://www.atipp.gov.nu.ca/en/Act. } \\
\text { aspx } \\
\text { *Nunavut Research Institute: } \\
\text { Licensing Process } \\
\text { http://www.nri.nu.ca/apps/authorin } \\
\text { g/dspPage.aspx?page=process }\end{array}$ & \begin{tabular}{|l} 
No legislative requirement. No \\
privacy office requirement.
\end{tabular} & $\begin{array}{l}\text { Those who want to conduct research } \\
\text { in Nunavut must hold a license issued } \\
\text { by the Nunavut Research Institute. }\end{array}$ & $\begin{array}{l}\text { Approval from public } \\
\text { body needed in } \\
\text { accordance with } \\
\text { section } 49 \text { of the } \\
\text { Access to Information } \\
\text { and Protection of } \\
\text { Privacy Act. }\end{array}$ & $\begin{array}{l}\text { Yes, according to sections } 23,24,43, \\
48 \text { of the Access to Information and } \\
\text { Protection of Privacy Act }\end{array}$ & $\begin{array}{l}\text { Section } 49(\mathrm{~b}) \text { of the Access to Information } \\
\text { and Protection of Privacy Act, a public } \\
\text { body may disclose information for } \\
\text { research if the record linkage is not } \\
\text { harmful and benefits are in public interest }\end{array}$ \\
\hline $\begin{array}{l}\text { Yukon } \\
\text { (Access to Information and } \\
\text { Protection of Privacy Act and the } \\
\text { Scientists and Explorers Act) } \\
\text { http://www.gov.yk.ca/legislation/ac } \\
\text { ts/atipp.pdf } \\
\text { Scientists and Explorers Act } \\
\text { http://www.tc.gov.yk.ca/pdf/scienti } \\
\text { sts_and_explorers_act.pdf }\end{array}$ & $\begin{array}{l}\text { Office of the Information and } \\
\text { Privacy Commissioner of the } \\
\text { Yukon recommends completion } \\
\text { and submission of an ATIPP } \\
\text { Compliance Assessment. } \\
\text { http://www.ombudsman.yk.ca/upl } \\
\underline{\text { oads/general/ACA_ATIPP_Comp }} \\
\underline{\text { liance_Assessment_August_2011 }} \\
\begin{array}{l}\text {.pdf } \\
\text { A PIA worksheet is also } \\
\text { available: } \\
\text { http://www.ombudsman.yk.ca/upl } \\
\text { oads/general/PRIVACY\%20IMP } \\
\text { ACT\%20ASSESSMENT.pdf }\end{array} \\
\end{array}$ & $\begin{array}{l}\text { According to the Scientists and } \\
\text { Explorers Act, research must be } \\
\text { conducted with a license issued by the } \\
\text { Minister. }\end{array}$ & $\begin{array}{l}\text { Approval from public } \\
\text { body needed in } \\
\text { accordance with } \\
\text { section } 38 \text { of the } \\
\text { Access to Information } \\
\text { and Protection of } \\
\text { Privacy Act. }\end{array}$ & $\begin{array}{l}\text { Yes, according to sections } 25,35 \text { and } \\
36 \text { of the Access to Information and } \\
\text { Protection of Privacy Act. }\end{array}$ & $\begin{array}{l}\text { According to Section } 38 \text { (b) Access to } \\
\text { Information and Protection of Privacy Act, } \\
\text { a public body may disclose information } \\
\text { for research if the record linkage is not } \\
\text { harmful and benefits are in public interest }\end{array}$ \\
\hline
\end{tabular}

